\title{
The Interaction of Carbon Monoxide with Rhodium \\ On Potassium-Modified $\mathrm{CeO}_{2}(111)$
}

\author{
David R. Mullins* \\ Chemical Sciences Division \\ Oak Ridge National Laboratory \\ Oak Ridge, TN 37831-6201
}

This manuscript has been authored by UT-Battelle, LLC under Contract No. DE-AC05-00OR22725 with the U.S. Department of Energy. The United States Government retains and the publisher, by accepting the article for publication, acknowledges that the United States Government retains a non-exclusive, paid-up, irrevocable, world-wide license to publish or reproduce the published form of this manuscript, or allow others to do so, for United States Government purposes. The Department of Energy will provide public access to these results of federally sponsored research in accordance with the DOE Public Access Plan (http://energy.gov/downloads/doe-public-access-plan).

*Corresponding Author:

David R. Mullins

Oak Ridge National Laboratory

PO Box 2008, MS 6201

Oak Ridge, TN 37831-6201

e-mail: mullinsdr@ornl.gov

phone: $865-574-2796$

FAX: 865-241-5252

(C) 2016. This manuscript version is made available under the Elsevier user license http://www.elsevier.com/open-access/userlicense/1.0/ 


\begin{abstract}
The adsorption and reactions of $\mathrm{CO}$ adsorbed on $\mathrm{Rh}$ particles deposited on $\mathrm{K}$-covered $\mathrm{CeO}_{2}(111)$ were studied by temperature programmed desorption and photoelectron spectroscopy. K deposited on $\mathrm{CeO}_{2}(111)$ forms a $\mathrm{KO}_{\mathrm{X}}$ over-layer by extracting $\mathrm{O}$ from the ceria and partially reducing some of the $\mathrm{Ce}^{4+}$ to $\mathrm{Ce}^{3+}$. $\mathrm{CO}$ does not adsorb on the $\mathrm{KO}_{\mathrm{X}} / \mathrm{CeO}_{2-\mathrm{X}}(111)$ surface in the absence of $\mathrm{Rh}$ particles. $\mathrm{CO}$ adsorbed on $\mathrm{Rh} / \mathrm{K} / \mathrm{CeO}_{2}(111)$ adsorbs molecularly on the $\mathrm{Rh}$ at $200 \mathrm{~K}$. As the surface is heated the $\mathrm{CO}$ spills-over and reacts with the $\mathrm{KO}_{\mathrm{X}}$ to form carbonate. The carbonate decomposes at elevated temperature to produce $\mathrm{CO}$ and $\mathrm{CO}_{2}$. The carbonate stabilizes the $\mathrm{KO}_{\mathrm{X}}$ so that $\mathrm{K}$ desorbs at a higher temperature than it would in the absence of $\mathrm{CO}$. When the $\mathrm{Rh}$ and $\mathrm{K}$ deposition are reversed so that $\mathrm{K}$ is deposited on both the $\mathrm{Rh}$ and the $\mathrm{CeO}_{2}(111), \mathrm{CO}$ adsorbs as $\mathrm{CO}_{2}{ }^{-}$at $200 \mathrm{~K}$. The $\mathrm{CO}_{2}{ }^{-}$decomposes below $350 \mathrm{~K}$ to produce gas phase $\mathrm{CO}$ and adsorbed $\mathrm{CO}_{3}{ }^{2-}$ and $\mathrm{CO}$. The $\mathrm{CO}$ is stabilized by the $\mathrm{K}$ on the $\mathrm{Rh}$ and desorbs above $540 \mathrm{~K}$. The carbonate decomposes into gas phase $\mathrm{CO}$ and $\mathrm{CO}_{2}$.
\end{abstract}




\section{Introduction}

The adsorption of alkali metals, and more specifically the co-adsorption of alkali metals and molecules, on surfaces has been studied extensively. Alkali metals are well-known "promoters" for catalytic reactions. In a review of alkali doping in heterogeneous catalysis Mross noted that alkalis can i) increase selectivity, ii) increase activity, and iii) prolong the lifetime of the catalyst.[1] Many fundamental surface science studies occurred in the 1980s culminating in a review by Bonzel. [2] Much of the surface science literature was devoted to the modification of $\mathrm{CO}$ adsorption and reaction on K-modified single crystal surfaces.[2-9] These studies were motivated by the wide-spread use of alkali promoters in Fischer-Tropschcatalysis[1,10] General observations from these studies indicated that $\mathrm{K}$ weakened the $\mathrm{CO}$ bond and strengthened the Metal-C bond.

There have been surprisingly few studies on $\mathrm{K}$ adsorption on well characterized metal oxide surfaces despite theincreasing attention to these surfaces in recent years.[11] From a practical point of view one can assume that alkalis added to industrial catalysts will be deposited on the oxide supports as well as the supported metal nanoparticles. Therefore it is of fundamental interest to determine how the alkalis may affect molecule-support interactions as well as molecule-metal interactions. There have been reports of $\mathrm{K}$ adsorption on $\mathrm{TiO}_{2}(100)[12]$, $\mathrm{TiO}_{2}(110)[13,14], \quad \mathrm{Cr}_{2} \mathrm{O}_{3}(0001)[15,16], \quad \mathrm{ZnO}(10 \overline{1} 0)[17,18], \quad \mathrm{MgO}(100)[19,20] \quad$ and $\mathrm{NiO}(100)$.[21] These studies did not report the influence of $\mathrm{K}$ on molecular adsorption, however.

An additional motivation for this current work is to explore the unique behavior that $\mathrm{CO}$ has when adsorbed on $\mathrm{Rh}$ supported on single crystal $\mathrm{CeO}_{\mathrm{X}}(111)$.[22-24] When $\mathrm{Rh}$ is supported on fully oxidized $\mathrm{CeO}_{2}(111), \mathrm{CO}$ adsorbs and desorbs much as it would on single crystal Rh surfaces with little interaction with or influence by the oxide support. However, when the Rh sits on partially reduced $\mathrm{CeO}_{2-\mathrm{x}}(111)$ the $\mathrm{CO}$ dissociates into $\mathrm{C}(\mathrm{a})$ and $\mathrm{O}(\mathrm{a})$ which ultimately recombine at an elevated temperature to desorb as $\mathrm{CO}$. On oxide and metal surfaces $\mathrm{K}$ has been shown to donate its valence electron to the substrate and adsorb as ionic $\mathrm{K}^{+}$. This behavior may mimic the interaction that may occur between reduced $\mathrm{Ce}^{3+}$ and a supported $\mathrm{Rh}$ particle. Either $\mathrm{K}^{0}$ might donate its electron to the $\mathrm{Rh}$ or to $\mathrm{Ce}^{4+}$ to produce $\mathrm{Ce}^{3+}$, in either case producing a situation which may promote $\mathrm{CO}$ dissociation on the $\mathrm{Rh}$. If $\mathrm{CO}$ dissociation is observed on $\mathrm{Rh} /$ $\mathrm{K} / \mathrm{CeO}_{2}(111)$ this may suggest an electronic effect is responsible for $\mathrm{CO}$ dissociation on $\mathrm{Rh} /$ $\mathrm{CeO}_{2-\mathrm{X}}(111)$. 
In a complex system such as $\mathrm{CO} / \mathrm{Rh} / \mathrm{K} / \mathrm{CeO}_{\mathrm{X}}(111)$ there is an extensive parameter space that could be investigated. In this investigation I have chosen to limit the $\mathrm{K}$ and $\mathrm{Rh}$ coveragesand the $\mathrm{CO}$ exposure to one reproducible set. In addition only initially fully oxidized $\mathrm{CeO}_{2}(111)$ is used as the starting substrate. A systematic variation in these coverage and oxidation state parameters, in particular the $\mathrm{K}$ coverage, will add further insight to the results presented in this paper.

This paper is organized as follows: the adsorption of $\mathrm{K}$ on $\mathrm{CeO}_{2}(111)$ without $\mathrm{Rh}$ or $\mathrm{CO}$ is presented first to establish the properties of the $\mathrm{K}$ adsorbate and its effect on the ceria support. $\mathrm{CO}$ adsorption will then be considered. $\mathrm{K}$ has a dramatic effect on the $\mathrm{CO}$ adsorption on $\mathrm{Rh}$ therefore, for comparison, TPD and photoemission data will be presented for CO adsorption on $\mathrm{Rh}, \mathrm{K} / \mathrm{Rh}$ and $\mathrm{Rh} / \mathrm{CeO}_{2}(111)$. There are two possible ways to deposit $\mathrm{Rh}$ and $\mathrm{K}$ on ceria; the $\mathrm{K}$ can be deposited first, followed the $\mathrm{Rh}$ (designated $\mathrm{Rh} / \mathrm{K} / \mathrm{CeO}_{2}(111)$ ) or the $\mathrm{Rh}$ can be deposited first followed by the $\mathrm{K}$ (designated $\mathrm{K} / \mathrm{Rh} / \mathrm{CeO}_{2}(111)$ ). Presumably the second method has a greater probability than the first for depositing $\mathrm{K}$ on the $\mathrm{Rh}$ particle in addition to $\mathrm{K}$ on the ceria. These two deposition orders produced strikingly different results and will be presented separately.

\section{Experimental}

The experiments were conducted in two different ultrahigh vacuum (UHV) chambers. Temperature programmed desorption (TPD)experiments were performed in a UHV chamber at Oak Ridge National Laboratory (ORNL). The temperature was ramped at $3 \mathrm{~K} / \mathrm{sec}$ and the sample was biased $-70 \mathrm{~V}$ to prevent electrons generated by the mass spectrometer ionizer from stimulating reactions at the surface. Auger electron spectroscopy (AES) and x-ray photoelectron spectroscopy (XPS) were used to determine the elemental composition of the surface and the Ce oxidation state, respectively. Ceria films were grown onto a $\mathrm{Ru}(0001)$ single crystal in situ by evaporating Ce metal under an $\mathrm{O}_{2}\left(2 \times 10^{-7}\right.$ Torr $)$ environment[25].

The $\mathrm{K}$ was evaporated onto the ceria film from an SAES getter source. A multilayer coverage of K was evaporated onto the sample at $200 \mathrm{~K}$ and then the sample was annealed to 350 $\mathrm{K}$ to remove multilayer $\mathrm{K}$ (see below). This procedure resulted in reproducible $\mathrm{K}$ coverages for all experiments. Rh was deposited from a resistively heated evaporative source while the sample was maintained at $300 \mathrm{~K}$. The Rh coverage was $8 \pm 1 \mathrm{~nm}^{-2}$. 
The samples were exposed to ${ }^{13} \mathrm{C}^{16} \mathrm{O}$ (Cambridge Isotope Labs) through a directional doser.[26] The $\mathrm{CO}$ contained ca. $10 \%{ }^{13} \mathrm{C}^{18} \mathrm{O}$ and the precise ratio of ${ }^{13} \mathrm{C}^{16} \mathrm{O}$ to ${ }^{13} \mathrm{C}^{18} \mathrm{O}$ was determined to be $11: 1$ by recording a TPD of the mixture from $\mathrm{Ru}(0001)$ before ceria was deposited. ${ }^{12} \mathrm{C}^{16} \mathrm{O}$ (Matheson) was used in the sXPS experiments. The gases were dosed to ensure saturation, i.e. further exposure resulted in no changes in the SXPS or TPD spectra. The typical exposure was approximately equal to $20 \mathrm{~L}$.

Soft-X-ray photoelectron spectroscopy (sXPS) was performed at beamline U12a at the National Synchrotron Light Source (NSLS). The experimental setup for these studies has also been previously described[27,28]. Ceria films, K and Rh were deposited as described above. The $\mathrm{C} 1 \mathrm{~s}$ and $\mathrm{K} 2 \mathrm{p}$ spectra were recorded using $410 \mathrm{eV}$ and $\mathrm{O} 1 \mathrm{~s}$ using $600 \mathrm{eV}$ photon excitation energies $(h v)$. The total instrumental resolution is less than $0.5 \mathrm{eV}$. On the ceria films the binding energies were calibrated relative to the Ce $4 \mathrm{~d}$ spectra $\left(\mathrm{X}^{\prime \prime \prime}-122.3 \mathrm{eV}\right)$ at the different photon energies.[29]In the absence of ceria the binding energies were referenced to the metallic Fermi edge. The Ce oxidation state was determined using the Ce $4 \mathrm{~d}$ spectra.[30]

\section{Results}

\subsection{Deposition of $\mathrm{K}$ on $\mathrm{CeO}_{2}(111)$}

Figure 1shows the TPD (Mass 39) of $\mathrm{K}$ onRu(0001) (black curve) and $\mathrm{CeO}_{2}(111)$ (red curve). The prominent peak near $330 \mathrm{~K}$ on both surfaces results from the desorption of multilayer $\mathrm{K}$. On metal surfaces the desorption of $\mathrm{K}$ is relatively structure-less and desorbs in a broad plateau from just above the multilayer peak to ca. 1000 K.[31] The onset temperature decreases monotonically with $\mathrm{K}$ coverage. The progressively decreasing adsorption energy has been related to repulsion between $\mathrm{K}$ atoms in the first layer.[31] A small feature labeled $\alpha$ has previously been reported between $550 \mathrm{~K}$ and $600 \mathrm{~K}$. A similar peak is evident in Figure 1 . The sharper feature near $640 \mathrm{~K}$ is associated with co-adsorbed $\mathrm{CO}$ that adsorbed on the surface during the $\mathrm{K}$ deposition.[5] The first monolayer coverage of $\mathrm{K}$ on $\mathrm{Ru}(0001)$ has been determined to be $0.36 \mathrm{ML}$ relative to the $\mathrm{Ru}(0001)$ surface density or $5.7 \mathrm{~nm}^{-2} \cdot[5,31]$

The TPD of $\mathrm{K}$ from $\mathrm{CeO}_{2}(111)$ (Figure 1 - red curve) displays a series of intense peaks at ca. $450 \mathrm{~K}, 630 \mathrm{~K}$ and $730 \mathrm{~K}$. The peak at $630 \mathrm{~K}$ and $450 \mathrm{~K}$ may be associated with the desorption of first and second layer $\mathrm{K}$, respectively, as reported for $\mathrm{K}$ desorption on $\mathrm{Cr}_{2} \mathrm{O}_{3}(0001)$.[16] The high temperature peak near $730 \mathrm{~K}$ may be related to the decomposition of 
$\mathrm{KO}_{\mathrm{X}}$ as has been reported for oxidized $\mathrm{K}$ films on $\mathrm{Ru}(0001)$.[32] It is clear from a visual comparison of Figure 1a and $1 \mathrm{~b}$ that a larger amount of $\mathrm{K}$ desorbs from $\mathrm{CeO}_{2}(111)$ than from $\mathrm{Ru}(0001)$ above the multilayer desorption temperature.

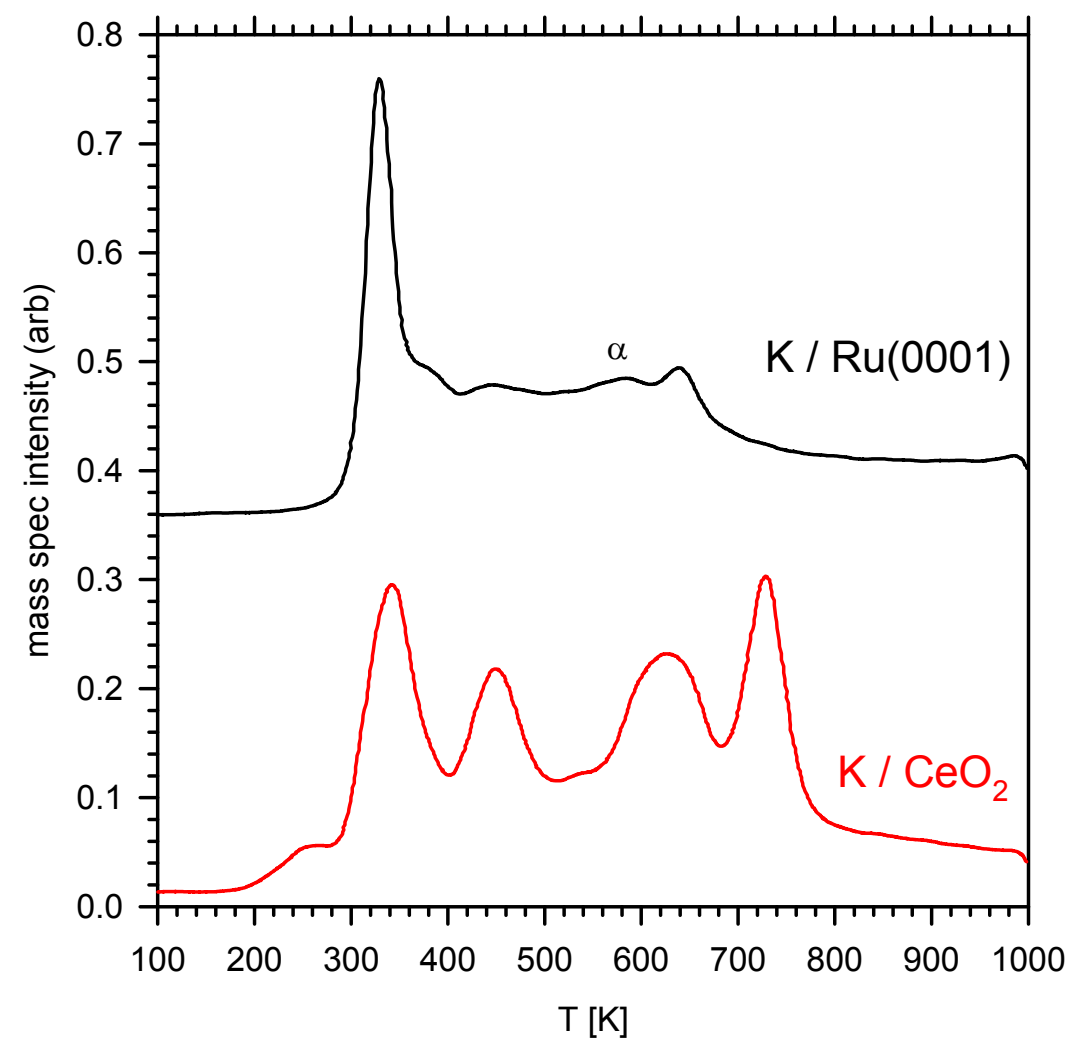

Figure $1-\mathrm{K}$ TPD following $\mathrm{K}$ deposition on $\mathrm{Ru}(0001)$ (black) and $\mathrm{CeO}_{2}(111)$ (red)at $200 \mathrm{~K}$.

Figures $2 \mathrm{a}$ and $2 \mathrm{~b}$ show the $\mathrm{K} 2 \mathrm{p}$ core-level spectra for $\mathrm{K}$ deposited on a) $\mathrm{Ru}(0001)$ and b) $\mathrm{CeO}_{2}(111)$ at $200 \mathrm{~K}$ and annealed as indicated. A Shirley background has been subtracted from all of the spectra.[33] The most prominent peaks in the $\mathrm{K} 2 \mathrm{p}$ spectra on $\mathrm{Ru}(0001)$ consist of a spin-orbit split doublet with $\mathrm{K} 2 \mathrm{p}_{3 / 2}$ at $293.8 \mathrm{eV}$ and $\mathrm{K} 2 \mathrm{p}_{1 / 2}$ at $296.6 \mathrm{eV}$. At $200 \mathrm{~K}$ and $300 \mathrm{~K}$ the peaks havesmall additional peaks at $0.9 \mathrm{eV}$ higher binding energies and broad asymmetric tails toward higher binding energies. The satellite peaks have been assigned to $\mathrm{K}$ in the second monolayer.[6] The tail has been interpreted as an indication of metallic character resulting from plasmons in the K.[34] When the sample was annealed to $400 \mathrm{~K}$, which is above the multilayer desorption temperature, the satellite peaks and the asymmetric tail largely disappear. As the sample is annealed to higher temperatures the intensity decreases as $\mathrm{K}$ desorbs and the peak positions shift to higher binding energies.[6] 


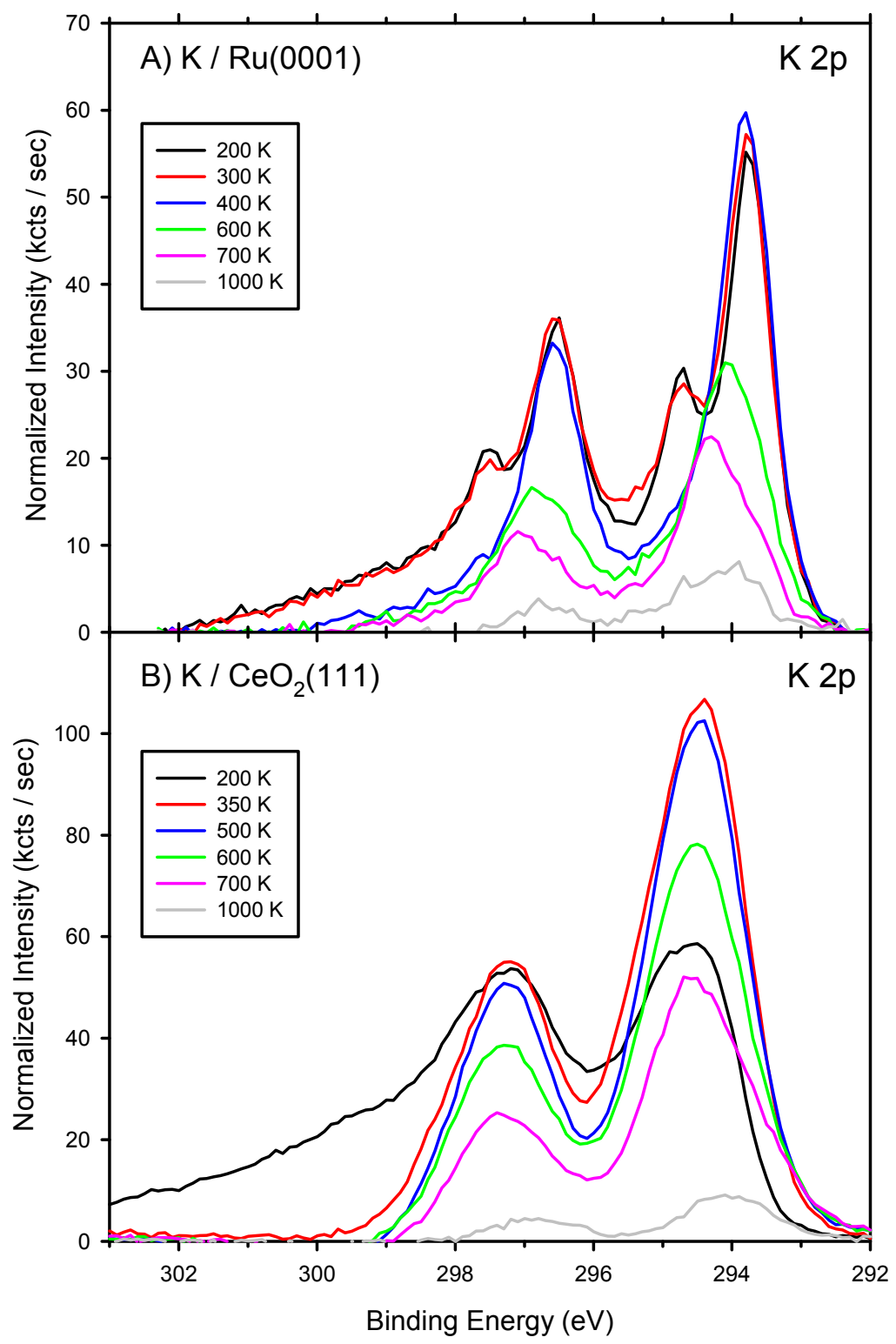

Figure $2-\mathrm{K} 2 \mathrm{p}$ spectra following $\mathrm{K}$ deposition on $\mathrm{A}) \mathrm{Ru}(0001)$ and $\mathrm{B}) \mathrm{CeO}_{2}(111)$ at $200 \mathrm{~K}$ and then annealed as indicated.

Following $\mathrm{K}$ deposition at $200 \mathrm{~K}$ on $\mathrm{CeO}_{2}(111)$ the $\mathrm{K} 2 \mathrm{p}$ spectrum(Figure $2 \mathrm{~b}$ ) has the asymmetric tail indicating metallic $\mathrm{K}$. The peaks are relatively broad and any satellite peaks are not readily evident in the spectra. When the sample was annealed to $350 \mathrm{~K}$ the asymmetric tail disappears however the peak heights actually increase and the integrated intensity remains constant. This behavior suggests a change in the state of the K, perhaps indicating an activated interaction with the $\mathrm{CeO}_{2}$ substrate. Note the difference in the vertical scale in Figures $2 \mathrm{a}$ and $2 \mathrm{~b}$ that indicates that the intensity is greater on $\mathrm{CeO}_{2}(111)$ compared to $\mathrm{Ru}(0001)$. At $350 \mathrm{~K}$ the $\mathrm{K}$ 
$2 \mathrm{p}_{3 / 2}$ and $\mathrm{K} 2 \mathrm{p}_{1 / 2}$ peaks are at $294.4 \mathrm{eV}$ and $297.2 \mathrm{eV}$, respectively. These peak positions stay fairly constant as the sample is annealed and $\mathrm{K}$ desorbs. At $700 \mathrm{~K}$ the peaks become distinctly asymmetric on the low binding energy side and at $1000 \mathrm{~K}$ the peak position has shifted to 294.0 $\mathrm{eV}$. The $\mathrm{K} 2 \mathrm{p}$ peaks on $\mathrm{CeO}_{2}(111)$ are broader than the $\mathrm{K} 2 \mathrm{p}$ peaks on $\mathrm{Ru}(0001)$ suggesting greater heterogeneity in the $\mathrm{K}$ on $\mathrm{CeO}_{2}(111)$. In addition, the $\mathrm{K} 2 \mathrm{p}$ peaks on $\mathrm{CeO}_{2}(111)$ have a higher binding energy, $\mathrm{K} 2 \mathrm{p}_{3 / 2}$ at $294.4 \mathrm{eV}$ vs. $293.8 \mathrm{eV}$, suggesting a higher oxidation state for the $\mathrm{K}$ on $\mathrm{CeO}_{2}(111)$.

The $\mathrm{K}$ coverage on $\mathrm{Ru}(0001)$ and $\mathrm{CeO}_{2}(111)$ are plotted as a function of temperature in Figure 3. The coverages were determined from the integrated K 2pcore level spectra intensities. TheK coverage in the first monolayer on $\mathrm{Ru}(0001)$ is $5.7 \mathrm{~nm}^{-2}$.[5]This coverage occurs after the multilayer desorbs at $400 \mathrm{~K}$. The $\mathrm{K}$ coverage at $350 \mathrm{~K}-400 \mathrm{~K}$ on $\mathrm{CeO}_{2}(111)$ is $13 \mathrm{~nm}^{-2}-14 \mathrm{~nm}^{-}$ ${ }^{2}$ or roughly twice the coverage on $\mathrm{Ru}(0001)$. In addition, whereas the coverage decays nearly linearly on $\mathrm{Ru}(0001)$ as the temperature is increased the coverage on $\mathrm{CeO}_{2}(111)$ displays some discontinuous decreases consistent with desorption peaks in Figure 1.

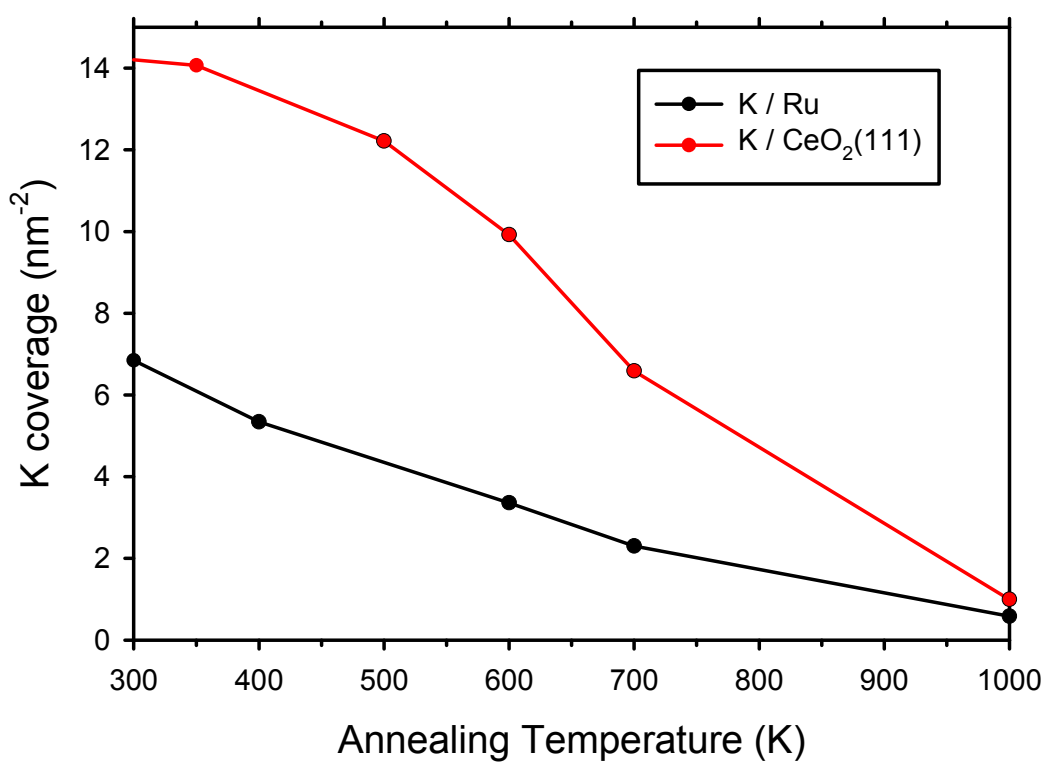

Figure 3 - $\mathrm{K}$ coverage following $\mathrm{K}$ deposition on $\mathrm{Ru}(0001)$ (black) and $\mathrm{CeO}_{2}(111)$ (red) at 200 $\mathrm{K}$ and then annealed to progressively higher temperatures.

Ce 3d core-level spectra, excited by a Mg ka laboratory source, are shown in Figure 4 as a function of annealing temperature after $\mathrm{K}$ deposition at $100 \mathrm{~K}$. The $\mathrm{K}$ over-layer attenuates the Ce photoemission by $35 \%$. To facilitate a comparison of these spectra a Shirley background was subtracted from the raw data and then the spectra were normalized to a constant total integrated 
intensity. Before $\mathrm{K}$ deposition the $\mathrm{Ce} 3 \mathrm{~d}$ spectrum from fully oxidized $\mathrm{CeO}_{2}(111)$ (black curve) consists of six peaks assigned to the Ce $3 \mathrm{~d}_{5 / 2}$ and $\mathrm{Ce} 3 \mathrm{~d}_{3 / 2}$ spin-orbit doublet and associated satellite features.[30] After K deposition the peaks at $916.7 \mathrm{eV}, 907.5 \mathrm{eV}$ and $889.0 \mathrm{eV}$ decrease in intensity while the valleys near $904 \mathrm{eV}$ and $885 \mathrm{eV}$ increase in intensity and a low binding energy shoulder emerges near $880 \mathrm{eV}$ (red curve). This behavior is indicative of the reduction of $\mathrm{Ce}^{4+}$ to $\mathrm{Ce}^{3+}$.[30] Based on the intensity decrease of the isolated $\mathrm{Ce}^{4+}$ peak at $916.7 \mathrm{eV}$ the degree of reduction is estimated to be $65 \% \mathrm{Ce}^{4+}$ or $\mathrm{CeO}_{1.83}(111)$. After the sample is annealed to $350 \mathrm{~K}$ to remove the $\mathrm{K}$ multilayer the Ce re-oxidizes slightly to $75 \% \mathrm{Ce}^{4+}$ (blue curve). After annealing to $900 \mathrm{~K}$ to remove most of the $\mathrm{K}$ the Ce $3 \mathrm{~d}$ spectrum (green curve) looks virtually identical to the spectrum from the surface before $\mathrm{K}$ deposition.

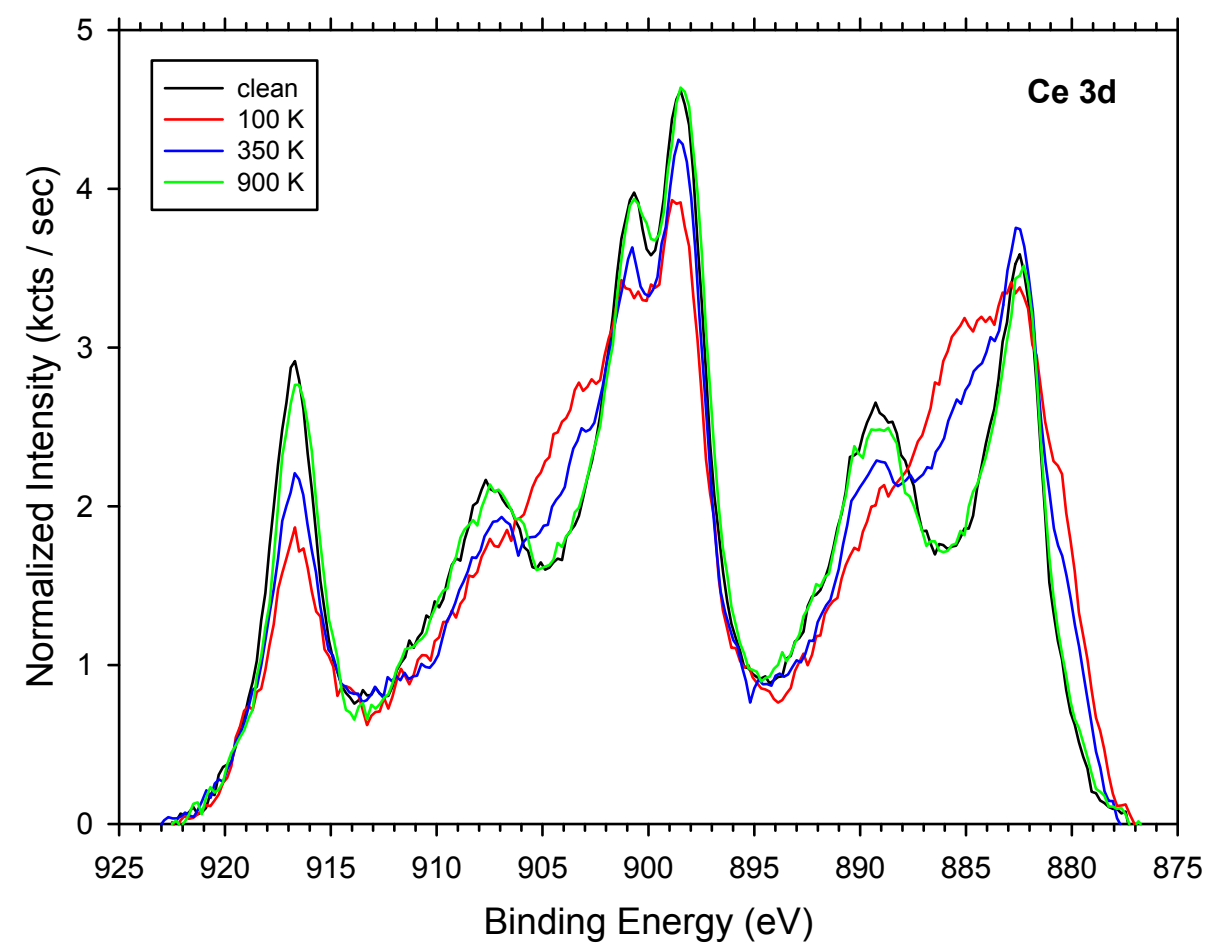

Figure $4-\mathrm{Ce} 3 \mathrm{~d}$ spectra following $\mathrm{K}$ deposition on $\mathrm{CeO}_{2}(111)$ at $100 \mathrm{~K}$ and then annealed as indicated. A Shirley background has been subtracted from all spectra and the spectra have been scaled to a constant integrated intensity to compensate for attenuation by the $\mathrm{K}$ overlayer.

The $\mathrm{Ce} 3 \mathrm{~d}$ spectra indicate that the $\mathrm{K}$ reacts with the $\mathrm{CeO}_{2}(111)$ surface to produce $\mathrm{KO}_{\mathrm{X}}$ and $\mathrm{CeO}_{2-\mathrm{x}}$. This reaction occurs even at $100 \mathrm{~K}$. When the sample was annealed to $350 \mathrm{~K}$ to desorb multilayer $\mathrm{K}$ the $\mathrm{Ce}$ is slightly re-oxidized. This suggests that $\mathrm{K}$ is oxidized into the multilayer at lower temperatures. The decomposition of $\mathrm{KO}_{\mathrm{X}}$ in the multilayer results in 
desorption of $\mathrm{K}$ and return of $\mathrm{O}$ to the $\mathrm{CeO}_{2-\mathrm{x}}$ substrate. An alternative interpretation of the apparent re-oxidation of $\mathrm{Ce}$ is that the $\mathrm{Ce} 3 \mathrm{~d}$ spectra at $100 \mathrm{~K}$ and $350 \mathrm{~K}$ reflect the distribution of $\mathrm{Ce}^{3+}$ as a function of depth within the $\mathrm{CeO}_{2-\mathrm{x}}(111)$ substrate. The $\mathrm{K}$ over-layer limits the depth from which $\mathrm{Ce} 3 \mathrm{~d}$ electrons can escape. The thicker over-layer at $100 \mathrm{Kresults}$ in more sensitivity to Ce near the $\mathrm{K} / \mathrm{CeO}_{2-\mathrm{X}}(111)$ interface. After desorption of $\mathrm{K}$ at $350 \mathrm{~K}$ the $\mathrm{Ce} 3 \mathrm{~d}$ XPS probes deeper into the ceria substrate. If Ce reduction is localized near the surface the average concentration of $\mathrm{Ce}^{4+}$ will increase as deeper layers are included in the spectra.

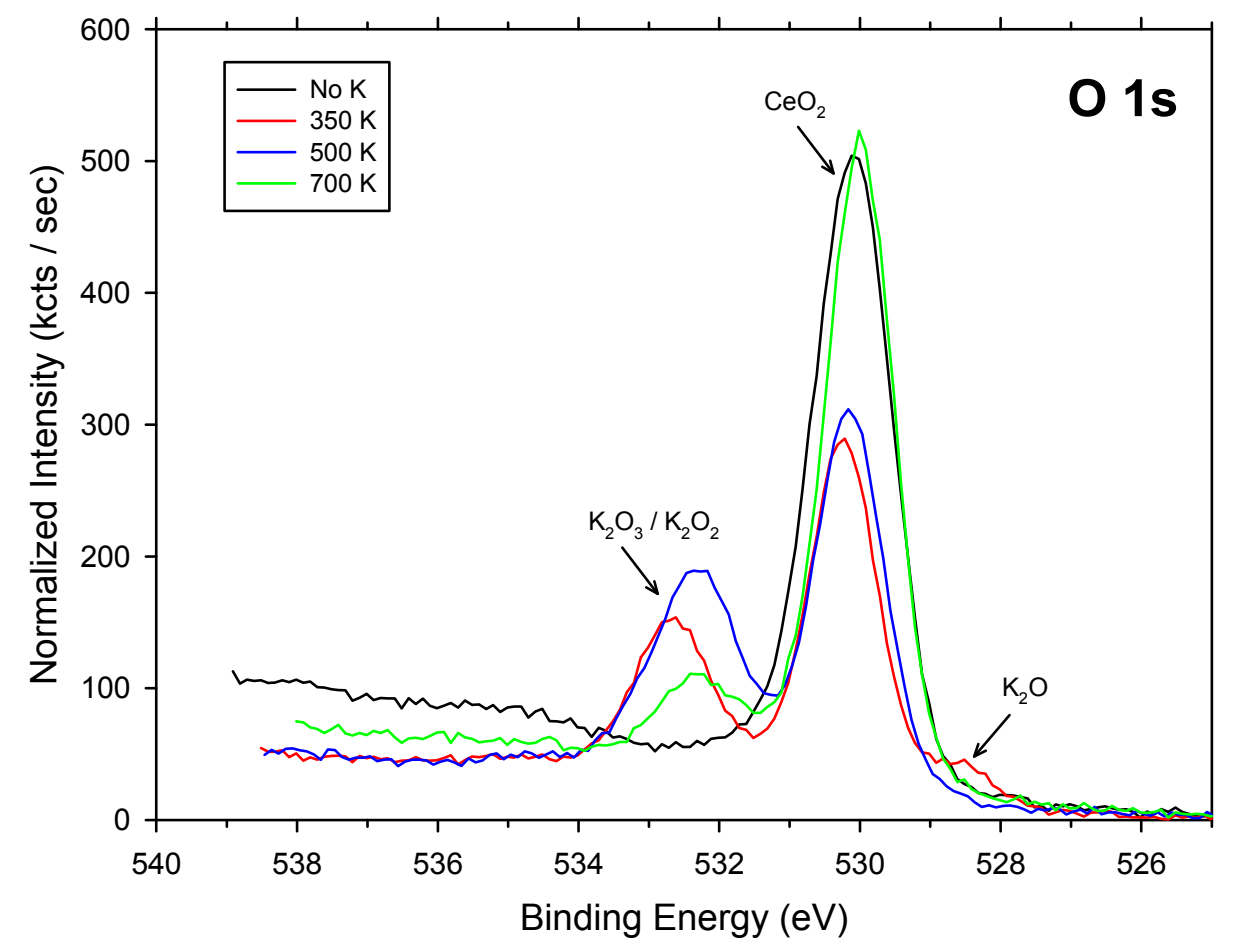

Figure $5-\mathrm{O} 1 \mathrm{~s}$ spectra following $\mathrm{K}$ deposition on $\mathrm{CeO}_{2}(111)$ at $200 \mathrm{~K}$ and then annealed as indicated.

Figure 5 shows the $\mathrm{O}$ 1s spectra from clean $\mathrm{CeO}_{2}(111)$ (black curve) and from K-covered $\mathrm{CeO}_{2}(111)$ annealed to various temperatures. The clean surface has a single $\mathrm{O} 1 \mathrm{~s}$ peak at 530.1 $\mathrm{eV}$. When $\mathrm{K}$ is adsorbed and annealed to $350 \mathrm{~K}$ (red curve) two new peaks appear at $532.7 \mathrm{eV}$ and $528.5 \mathrm{eV}$. The peak at $532.7 \mathrm{eV}$ shifts to $532.3 \mathrm{eV}$ when the sample is annealed from $350 \mathrm{~K}$ to $500 \mathrm{~K}$ and the peak at $528.5 \mathrm{eV}$ disappears. Lamontagne et al assigned $\mathrm{O}$ 1s peaks near 527 $\mathrm{eV}-528 \mathrm{eV}$ to $\mathrm{K}_{2} \mathrm{O}$, peaks near $531 \mathrm{eV}$ to $\mathrm{K}_{2} \mathrm{O}_{2}$, peaks near $532 \mathrm{eV}$ to $\mathrm{K}_{2} \mathrm{O}_{3}$ and peaks near 534 $\mathrm{eV}$ to $\mathrm{K}_{2} \mathrm{O}_{3}$.[35] Therefore peaks above the $\mathrm{CeO}_{2}$ peak at $530.1 \mathrm{eV}$ are assigned to a mixture of $\mathrm{K}_{2} \mathrm{O}_{3}$ and $\mathrm{K}_{2} \mathrm{O}_{2}$ while the peak at $528.5 \mathrm{eV}$ is assigned to $\mathrm{K}_{2} \mathrm{O}$. When the sample is annealed to 
$700 \mathrm{~K}$ (green curve) the $\mathrm{K}_{2} \mathrm{O}_{3} / \mathrm{K}_{2} \mathrm{O}_{2}$ peak is diminished and the $\mathrm{CeO}_{2}$ peak grows consistent with the desorption of $\mathrm{K}$.

Both the $\mathrm{Ce} 3 \mathrm{~d}$ and $\mathrm{O} 1 \mathrm{~s}$ spectra indicate that adsorbed $\mathrm{K}$ reacts with the $\mathrm{CeO}_{2}(111)$ surface to form $\mathrm{KO}_{\mathrm{X}}$. The removal of $\mathrm{O}$ from the ceria, and the transfer of an electron from $\mathrm{K}$ to $\mathrm{Ce}$, reduces $\mathrm{Ce}^{4+}$ to $\mathrm{Ce}^{3+}$.

\subsection{CO adsorption on $\mathrm{K} / \mathrm{Rh}$}

CO was adsorbed on $\mathrm{Rh} / \mathrm{Ru}(0001)$ and on $\mathrm{K} / \mathrm{Rh} / \mathrm{Ru}(0001)$ for comparisons to what is observed when $\mathrm{Rh}$ is supported on $\mathrm{CeO}_{2}(111)$. As noted below, the results are consistent with what has been reported for $\mathrm{CO} / \mathrm{Rh}(111)$ and $\mathrm{CO} / \mathrm{K} / \mathrm{Rh}(111)$.[4]

A thick film of $\mathrm{Rh}$ was deposited on $\mathrm{Ru}(0001)$ at $300 \mathrm{~K}$ and then annealed to $900 \mathrm{~K}$. Based on the attenuation of the Ru AES and Ru $2 p$ XPS signals the Rh over-layer was estimated to be greater than $4 \mathrm{~nm}$.[36,37] Figure 6a shows the desorption of ${ }^{13} \mathrm{C}^{16} \mathrm{O}$ and ${ }^{13} \mathrm{C}^{18} \mathrm{O}$ following exposure at $200 \mathrm{~K}$. The ${ }^{13} \mathrm{C}^{18} \mathrm{O}$ has been scaled so that it matches the desorption of the ${ }^{13} \mathrm{C}^{16} \mathrm{O}$ and reflects their relative compositions in the $\mathrm{CO}$ source. The $\mathrm{CO}$ desorbs in a broad peak with a peak maximum at ca. $455 \mathrm{~K}$. K was than deposited on the $\mathrm{Rh}$ film at $200 \mathrm{~K}$ and then annealed to $500 \mathrm{~K}$. Assuming the $\mathrm{K}$ over-layer behaves similarly on $\mathrm{Ru}$ and $\mathrm{Rh}$, i.e. the monolayer coverages are similar on the two surfaces, $[4,5]$ the $\mathrm{K}$ coverage was ca. $4 \mathrm{~nm}^{-2}$ (Figure 3). The $\mathrm{K} / \mathrm{Rh}$ film was then exposed to $\mathrm{CO}$ at $200 \mathrm{~K}$. The $\mathrm{CO}$ desorption was delayed until higher temperature compared to $\mathrm{CO}$ on the clean Rh film (Figure 6a and 6b). A prominent peak occurred at ca. 660 $\mathrm{K}$ with a shoulder at ca. $580 \mathrm{~K}$. The $\mathrm{K}$ desorption coincided with the high temperature $\mathrm{CO}$ desorption at $660 \mathrm{~K}$. Note that the $\mathrm{K}$ desorption is also delayed compared to $\mathrm{K} / \mathrm{Rh}$ without $\mathrm{CO}$ where the desorption would have started at $500 \mathrm{~K}$, i.e. the annealing temperature before $\mathrm{CO}$ exposure. The desorption behavior of $\mathrm{CO}$ on clean and $\mathrm{K}$-covered $\mathrm{Rh}$ is completely consistent with the results reported by Crowell and Somorjai on $\mathrm{Rh}(111)$.[4] Note in Figure $6 \mathrm{~b}$ that the ${ }^{13} \mathrm{C}^{16} \mathrm{O}$ desorption and the ${ }^{13} \mathrm{C}^{18} \mathrm{O}$ desorption scaled as in Figure 6a again overlap perfectly. In subsequent results a decrease in the relative intensity of the ${ }^{13} \mathrm{C}^{18} \mathrm{O}$ compared to ${ }^{13} \mathrm{C}^{16} \mathrm{O}$ will indicate an exchange of $\mathrm{O}$ between the $\mathrm{CO}$ adsorbate and the oxide substrate. 


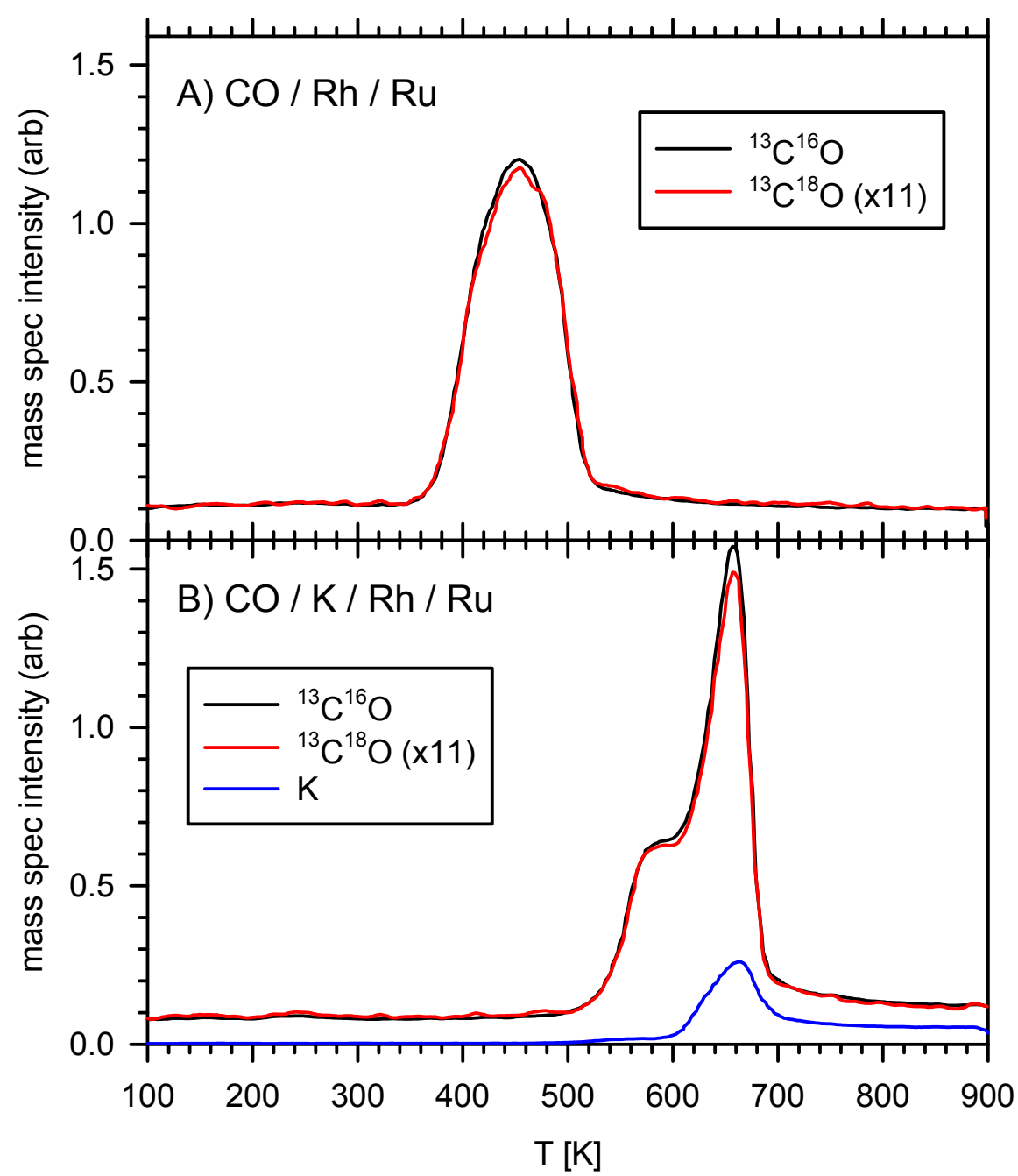

Figure 6 - TPD following $\mathrm{CO}$ adsorption at $200 \mathrm{~K}$ on $\mathrm{A}) \mathrm{Rh} / \mathrm{Ru}(0001)$ and $\mathrm{B}) \mathrm{K} / \mathrm{Rh}$ / $\mathrm{Ru}(0001)$.

Figure 7 shows the $\mathrm{C} 1 \mathrm{~s}$ XPS for $\mathrm{CO}$ on the clean $\mathrm{Rh}$ film and $\mathrm{CO}$ on $\mathrm{K} / \mathrm{Rh}$. On the clean $\mathrm{Rh}$ film the CO produces a single peak at $286.4 \mathrm{eV}$. Note that the $\mathrm{Ru} 3 \mathrm{~d}_{3 / 2}$ peak is visible from the buried substrate but has been attenuated ca. 500x compared to clean $\mathrm{Ru}(0001)$. The $\mathrm{CO}$ was flashed off, $\mathrm{K}$ was evaporated on to the Rh surface at $200 \mathrm{~K}$ which was then annealed to $500 \mathrm{~K}$ and then $\mathrm{CO}$ re-exposed onto the $\mathrm{K} / \mathrm{Rh}$ surface. The $\mathrm{CO}$ peak position shifted to $285.1 \mathrm{eV}$. This is consistent with the C 1s XPS results reported by Strisland et al for $\mathrm{CO} / \mathrm{K} / \mathrm{Rh}(111)$.[38] They assigned the $\mathrm{CO}$ at the higher binding energy, that occurred in the absence of $\mathrm{K}$, to $\mathrm{CO}$ adsorbed in an atop site and the $\mathrm{CO}$ at the lower binding energy, that occurred when $\mathrm{K}$ was present, to $\mathrm{CO}$ adsorbed in a hollow site. 


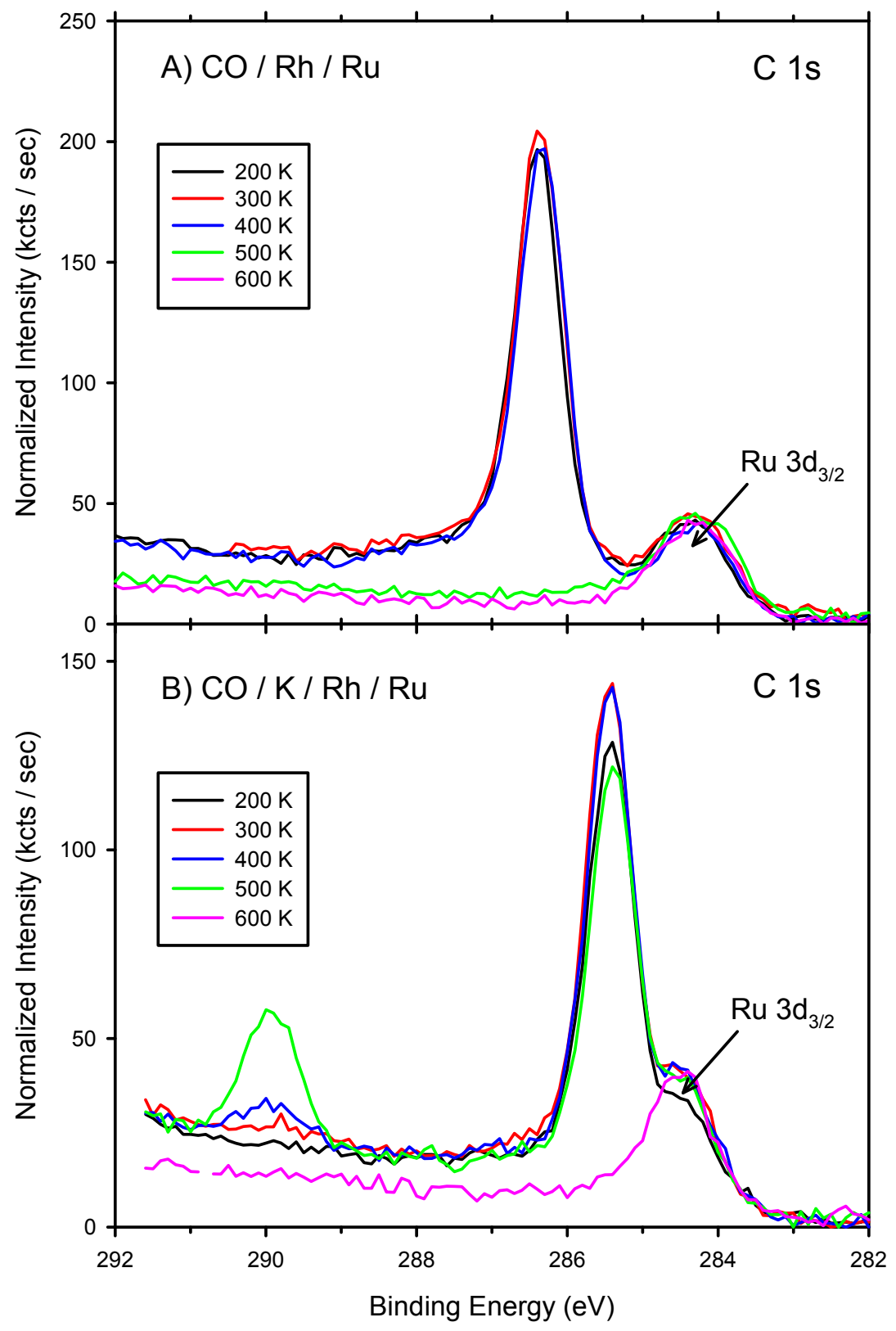

Figure 7 - C 1s spectra following CO adsorption on A) $\mathrm{Rh} / \mathrm{Ru}(0001)$ and $\mathrm{B}) \mathrm{K} / \mathrm{Rh} / \mathrm{Ru}(0001)$ at $200 \mathrm{~K}$ then annealed as indicated.

The $\mathrm{CO}$ was completely removed from the $\mathrm{K}$-free surface after annealing to $500 \mathrm{~K}$ (Figure 7a) while the $\mathrm{CO}$ remained on the surface at $500 \mathrm{~K}$ when $\mathrm{K}$ was present (Figure $7 \mathrm{~b}$ ). This is consistent with the delayed CO desorption observed in the TPD (Figure 6b) due to $\mathrm{CO}-\mathrm{K}$ interaction. A new feature appeared near $290 \mathrm{eV}$ at higher temperatures on the $\mathrm{CO} / \mathrm{K} / \mathrm{Rh}$ surface. This is assigned to carbonate, $\mathrm{CO}_{3}{ }^{2-}$, that presumably formed from a reaction between $\mathrm{CO}$ and $\mathrm{O}$ that adsorbed on the surface during $\mathrm{K}$ deposition. 


\section{$3.3 \mathrm{CO}$ adsorption on $\mathrm{Rh} / \mathrm{K} / \mathrm{CeO}_{2}(111)$}

TPD and C 1s core-level photoemission indicated that CO did not adsorb on Rh-free $\mathrm{CeO}_{2}(111)$, with or without the presence of $\mathrm{K}$. Therefore a metal particle is necessary for $\mathrm{CO}$ adsorption.[22,28] The desorption of $\mathrm{CO}$ from $\mathrm{Rh} / \mathrm{CeO}_{2}(111)$ is essentially the same as has been reported for $\mathrm{CO}$ on $\mathrm{Rh}(111)$.[4] As shown in Figure 8a after exposure at $200 \mathrm{~K}$ the $\mathrm{CO}$ desorbs from the $\mathrm{Rh}$ in a broad doublet between ca. $300 \mathrm{~K}$ and $550 \mathrm{~K}$. The ${ }^{13} \mathrm{C}^{16} \mathrm{O}$ and scaled ${ }^{13} \mathrm{C}^{18} \mathrm{O}$ signals no longer match which indicates a small loss of ${ }^{18} \mathrm{O}$ from the ${ }^{13} \mathrm{C}^{18} \mathrm{O}$ adsorbate due to exchange with the $\mathrm{Ce}^{16} \mathrm{O}_{2}$ substrate. There is also some ${ }^{13} \mathrm{C}^{16} \mathrm{O}_{2}$ formed through reaction of ${ }^{13} \mathrm{C}^{16} \mathrm{O}$ with the $\mathrm{Ce}^{16} \mathrm{O}_{2}$.

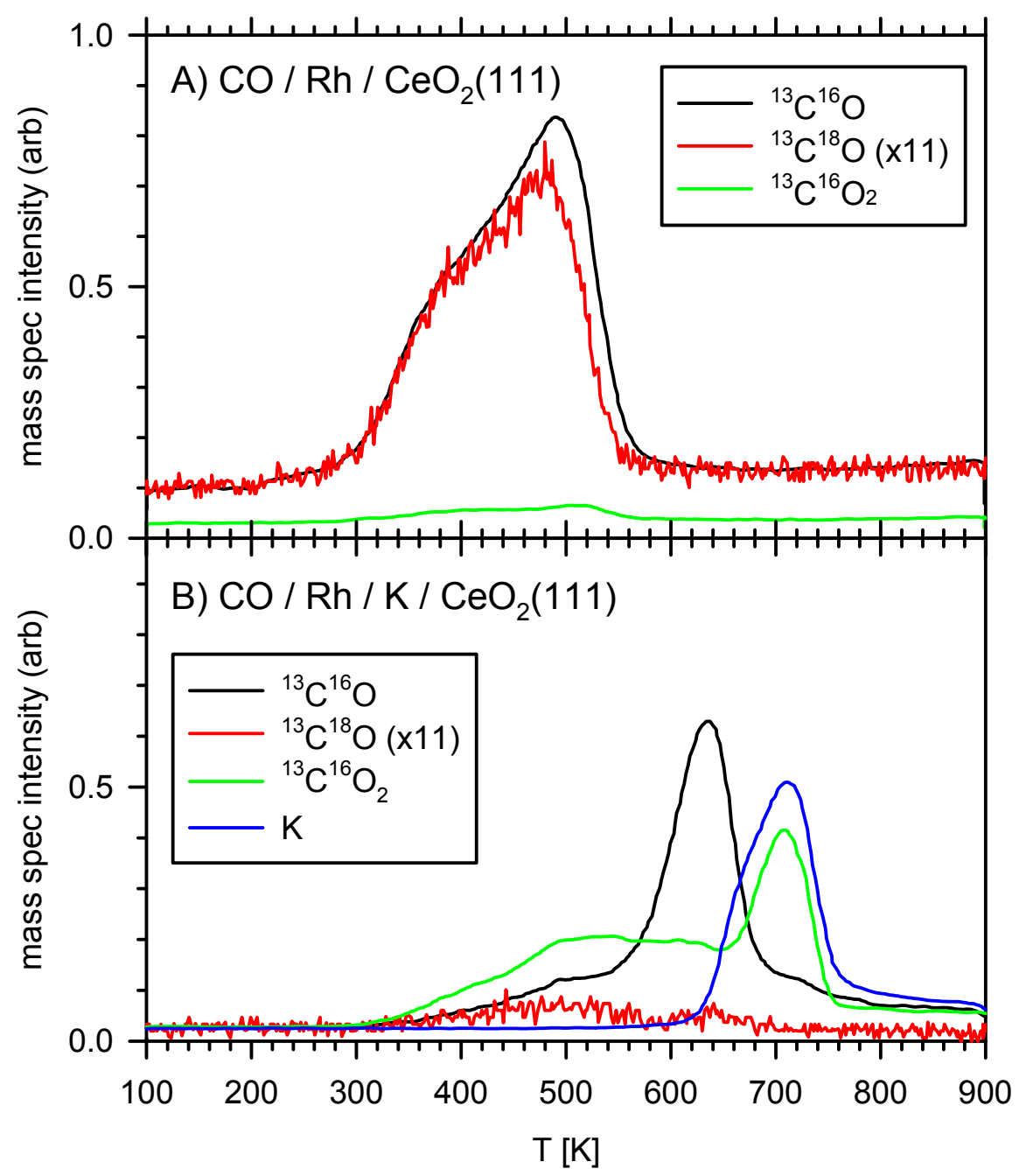

Figure 8 - TPD following $\mathrm{CO}$ adsorption at $200 \mathrm{~K}$ on A) $\mathrm{Rh} / \mathrm{CeO}_{2}(111)$ and $\left.\mathrm{B}\right) \mathrm{Rh} / \mathrm{K} /$ $\mathrm{CeO}_{2}(111)$. 
$\mathrm{K}$ was evaporated onto the $\mathrm{CeO}_{2}(111)$ at $200 \mathrm{~K}$ and then annealed to $400 \mathrm{~K}$ to remove the $\mathrm{K}$ multilayer and leave a $\mathrm{K}$ coverage of $13 \mathrm{~nm}^{-2}-14 \mathrm{~nm}^{-2}$ (Figure 3). Rh was then deposited on the $\mathrm{K} / \mathrm{CeO}_{2}(111)$ substrate at $300 \mathrm{~K}$ followed by $\mathrm{CO}$ exposure at $200 \mathrm{~K}$. The resulting TPD (Figure 8b) is totally different from either $\mathrm{CO}$ on $\mathrm{Rh} / \mathrm{CeO}_{2}(111)$ (Figure 8a) or $\mathrm{CO}$ on $\mathrm{K} / \mathrm{Rh}$ (Figure $6 \mathrm{~b}$ ). $\mathrm{K}$ desorption is again delayed until ca. $700 \mathrm{~K}$, as on the $\mathrm{CO} / \mathrm{K} / \mathrm{Rh}$ surface, but instead of the $\mathrm{K}$ desorption coinciding with $\mathrm{CO}$ it desorbs in a peak coincident with $\mathrm{CO}_{2}$. In addition to the peak at $700 \mathrm{~K}, \mathrm{CO}_{2}$ desorbs in a broad feature that starts near $320 \mathrm{~K} \cdot{ }^{13} \mathrm{C}^{16} \mathrm{O}$ has a prominent peak near $620 \mathrm{~K}$ as well as broad shoulders on both the low and high temperature sides. There is an almost total loss of ${ }^{13} \mathrm{C}^{18} \mathrm{O}$ which, along with the production of $\mathrm{CO}_{2}$, indicates a strong interaction of the $\mathrm{CO}$ with the $\mathrm{O}$ in the substrate.

The $\mathrm{C}$ 1s core-level spectra for $\mathrm{CO}$ on $\mathrm{Rh} / \mathrm{CeO}_{2}(111)$ are shown in Figure 9a. Following exposure at $200 \mathrm{~K}$ the spectrum is dominated by a peak at $286 \mathrm{eV}$ with a small peak near $290 \mathrm{eV}$. The peak at $286 \mathrm{eV}$ is assigned to $\mathrm{CO}$ adsorbed in an atop site on the $\mathrm{Rh}$ particle.[38] The peak at $290 \mathrm{eV}$ is assigned to carbonate, $\mathrm{CO}_{3}{ }^{2-}$.[39] The intensity from these species diminishes significantly after the sample is annealed to $500 \mathrm{~K}$ as most of the $\mathrm{CO}$ has desorbed (Figure 8a). All of the C-containing species are removed from the surface at $700 \mathrm{~K}$.

The $\mathrm{C}$ 1s spectra for the $\mathrm{CO} / \mathrm{Rh} / \mathrm{K} / \mathrm{CeO}_{2}(111)$ surface, prepared the same way as for the TPD spectra in Figure 8b, are shown in Figure 9b. At $350 \mathrm{~K}$ the spectrum is similar to the spectrum for $\mathrm{CO}$ on $\mathrm{Rh} / \mathrm{CeO}_{2}(111)$ (Figure 9a) with peaks at $286 \mathrm{eV}$ and $290.3 \mathrm{eV}$. The carbonate peak is somewhat more prominent on the K-modified surface. Note that there is a change in scale between Figures 9a and $9 \mathrm{~b}$ and the intensity of the CO-related peak at $286 \mathrm{eV}$ is about the same in both spectra.

As the sample is annealed the $\mathrm{CO}$ peak diminishes but the carbonate peak increases and reaches a maximum intensity near $600 \mathrm{~K}$. Comparing the $\mathrm{C} 1 \mathrm{~s}$ spectra with the TPD spectra it appears that carbonate decomposes into both $\mathrm{CO}$ and $\mathrm{CO}_{2}$ at high temperature. $\mathrm{CO}$ apparently contributes to the $\mathrm{CO}_{2}$ desorption but it isn't clear whether it proceeds to $\mathrm{CO}_{2}$ through a carbonate intermediate or through direct reaction with $\mathrm{O}$ in the substrate. The total integrated $\mathrm{C}$ 1s intensity increases as the sample is annealed from $350 \mathrm{~K}$ to $600 \mathrm{~K}$ despite the desorption of $\mathrm{CO}$ and $\mathrm{CO}_{2}$ in this temperature range. One possible explanation is that the intensity of the carbonate peak was affected by diffraction effects. Another possible explanation is that the 
carbonate was initially formed subsurface and later emerged to the surface as the sample was heated. This anomalous behavior of the $\mathrm{C} 1 \mathrm{~s}$ intensity was not explored further.

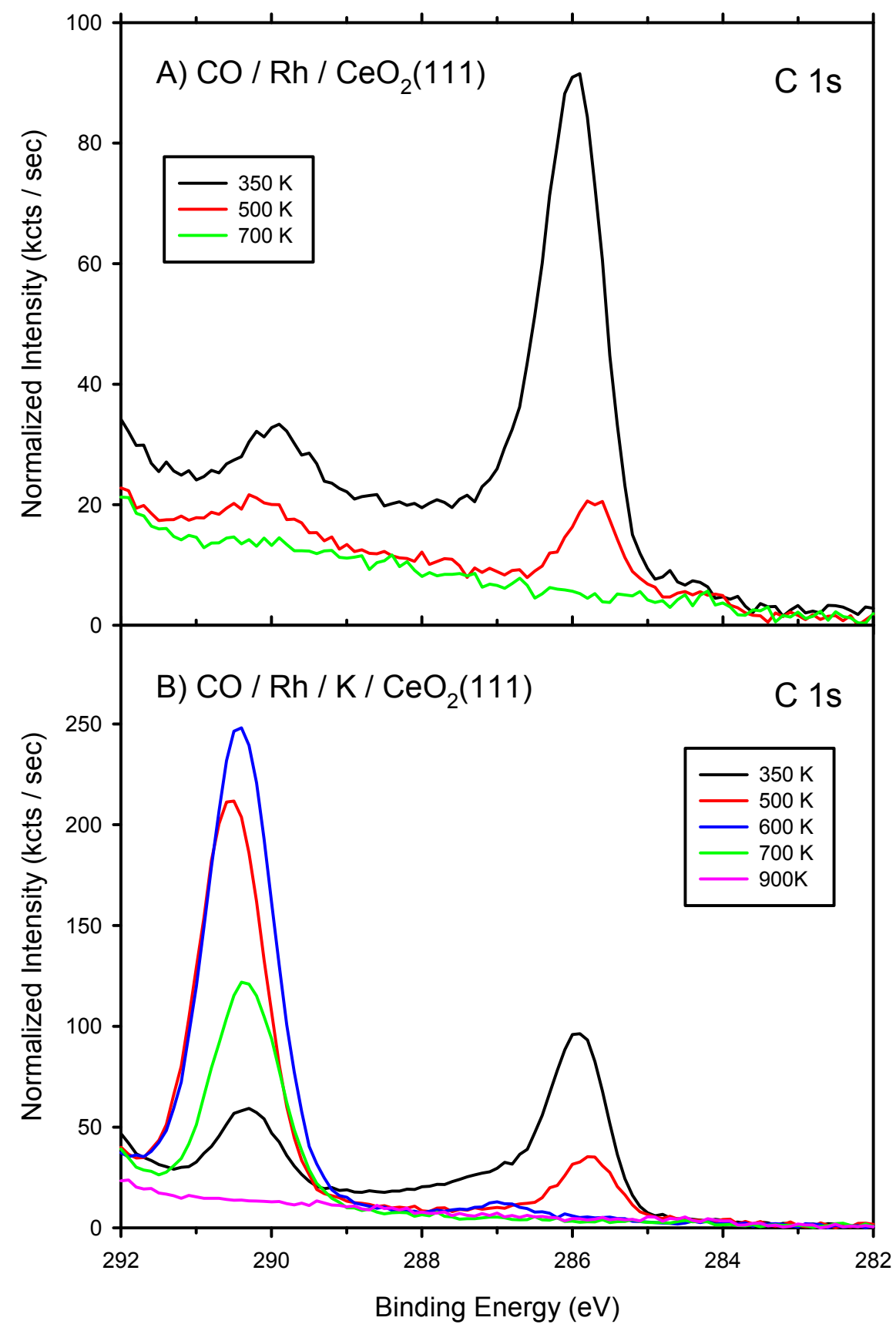

Figure 9 - C 1s spectra following $\mathrm{CO}$ adsorption on A) $\mathrm{Rh} / \mathrm{CeO}_{2}(111)$ and $\left.\mathrm{B}\right) \mathrm{Rh} / \mathrm{K} /$ $\mathrm{CeO}_{2}(111)$ at $200 \mathrm{~K}$ and then annealed as indicated. 


\section{$3.4 \mathrm{CO}$ on $\mathrm{K} / \mathrm{Rh} / \mathrm{CeO}_{2}(111)$}

The deposition order of $\mathrm{K}$ and $\mathrm{Rh}$ was reversed, i.e. $\mathrm{Rh}$ was first evaporated ontothe $\mathrm{CeO}_{2}(111)$ surface then $\mathrm{K}$ was deposited onto $\mathrm{Rh} / \mathrm{CeO}_{2}(111)$ and annealed to $400 \mathrm{~K}$. This presumably produced the same coverages of $\mathrm{Rh}$ and $\mathrm{K}$ on the ceria as in Section 3.3 but $\mathrm{K}$ was deposited on both the $\mathrm{Rh}$ and the $\mathrm{CeO}_{2}(111)$. The resulting TPD after $\mathrm{CO}$ exposure is shown in Figure 10.

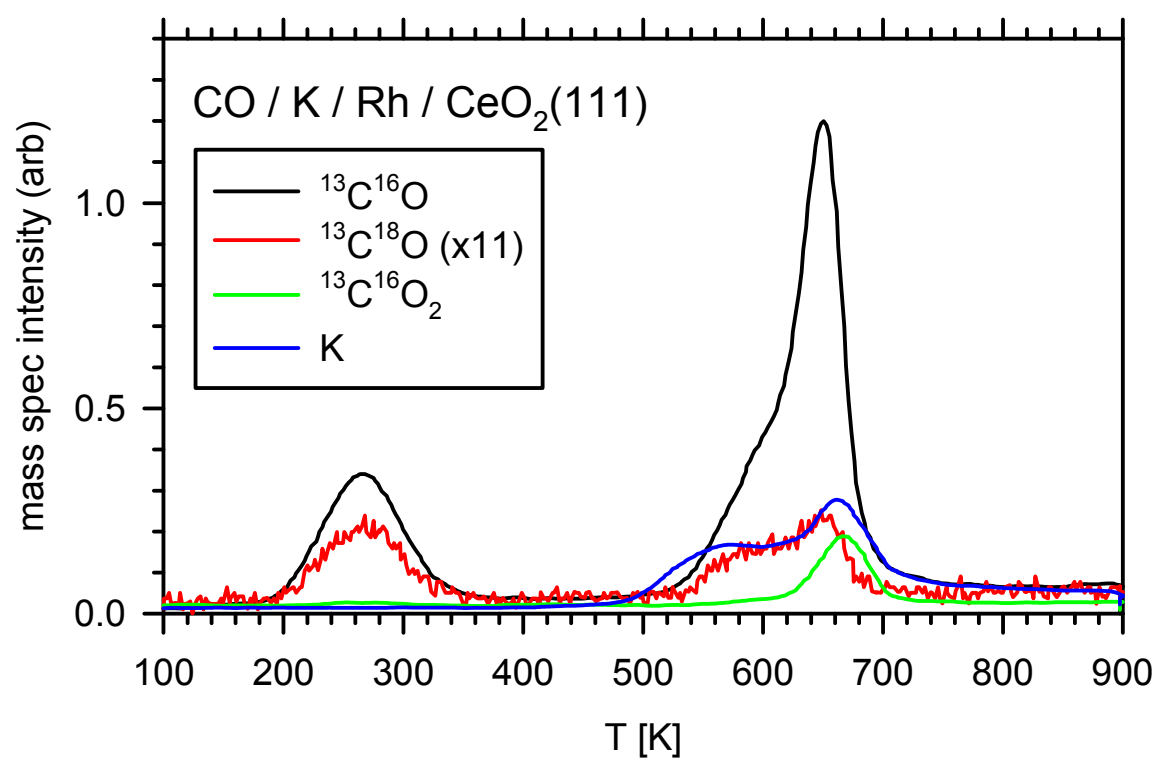

Figure 10 - TPD following $\mathrm{CO}$ adsorption at $200 \mathrm{~K}$ on $\mathrm{K} / \mathrm{Rh} / \mathrm{CeO}_{2}(111)$.

Again the TPD is dramatically different from the $\mathrm{Rh} / \mathrm{CeO}_{2}(111)$ surface without $\mathrm{K}$ (Figure 8a) but is also very different from the $\mathrm{Rh} / \mathrm{K} / \mathrm{CeO}_{2}(111)$ surface (Figure $8 \mathrm{~b}$ ). The $\mathrm{CO}$ desorption splits into two regions, a single peak between $200 \mathrm{~K}$ and $300 \mathrm{~K}$ and a doublet between $500 \mathrm{~K}$ and $700 \mathrm{~K}$. The high temperature region between $500 \mathrm{~K}$ and $700 \mathrm{~K}$ is similar to the $\mathrm{CO}$ desorption that occurred on $\mathrm{CO} / \mathrm{K} / \mathrm{Rh}$ (Figure 6b). The $\mathrm{CO}_{2}$ desorption is diminished compared to the case of $\mathrm{CO} / \mathrm{Rh} / \mathrm{K} / \mathrm{CeO}_{2}$ (Figure 8b). Only a small $\mathrm{CO}_{2}$ peak is evident coincident with the $\mathrm{K}$ and $\mathrm{CO}$ peaks near $660 \mathrm{~K}$. Compared to the $\mathrm{K}$ desorption from $\mathrm{CO} / \mathrm{K} /$ $\mathrm{Rh}$ (Figure 6b) the $\mathrm{K}$ desorbs between $500 \mathrm{~K}$ and $600 \mathrm{~K}$ in addition to the peak coincident with $\mathrm{CO}$ at $660 \mathrm{~K}$. This may be $\mathrm{K}$ that is not interacting with the $\mathrm{CO}$, such as $\mathrm{K}$ on the $\mathrm{CeO}_{2}$. Finally the $\mathrm{CO}$ between $200 \mathrm{~K}$ and $300 \mathrm{~K}$ is unique to this surface. An analogous weakly bound $\mathrm{CO}$ species was not observed in any of the other permutations of $\mathrm{CO} / \mathrm{K} / \mathrm{Rh} / \mathrm{CeO}_{2}(111)$. 


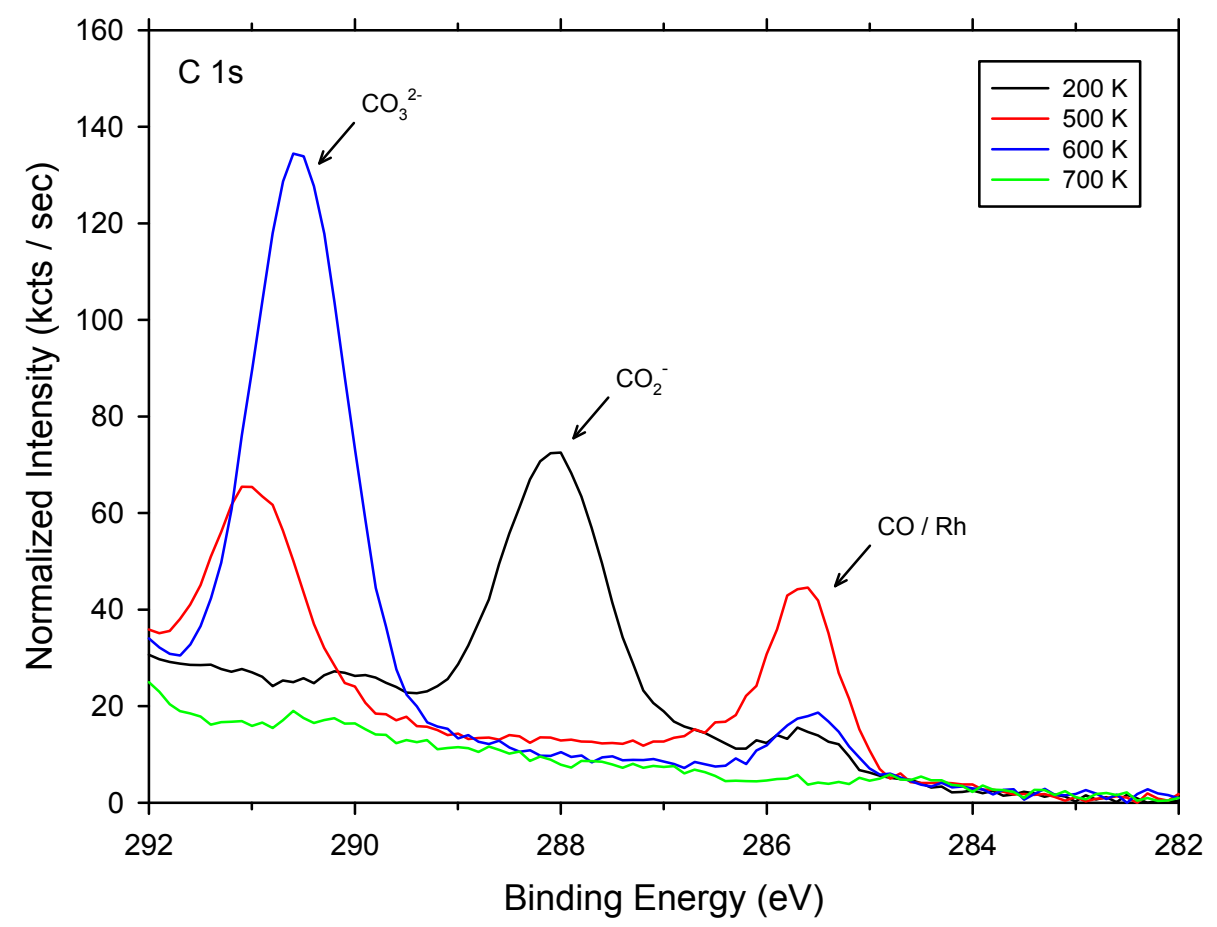

Figure $11-\mathrm{C} 1$ s spectra following $\mathrm{CO}$ adsorption on $\mathrm{K} / \mathrm{Rh} / \mathrm{CeO}_{2}(111)$ at $200 \mathrm{~K}$ and then annealed as indicated.

The $\mathrm{C}$ 1s spectra for this system, $\mathrm{CO} / \mathrm{K} / \mathrm{Rh} / \mathrm{CeO}_{2}(111)$, are shown in Figure 11. Upon adsorption of $\mathrm{CO}$ at $200 \mathrm{~K}$ a new feature that wasn't observed in any of the other spectra is evident at $288 \mathrm{eV}$. This binding energy indicates a species with $\mathrm{C}$ having an oxidation state that lies between $\mathrm{CO}(+2)$ and $\mathrm{CO}_{3}{ }^{2-}(+4)$. A likely candidate is $\mathrm{CO}_{2}{ }^{-}$which has been identified as a surface intermediate following $\mathrm{CO}_{2}$ adsorption on several K-covered metals surfaces.[4043] Oxalate, $\left(\mathrm{C}_{2} \mathrm{O}_{4}\right)^{2-}$, would also be consistent with this binding energy since the $\mathrm{C}$ has the same nominal oxidation state as in $\mathrm{CO}_{2}^{-}$. The XPS data cannot differentiate between these two species. The $\mathrm{C} 1 \mathrm{~s}$ feature at $288 \mathrm{eV}$ appears to be associated with the low temperature $\mathrm{CO}$ desorption from $\mathrm{CO} / \mathrm{K} / \mathrm{Rh} / \mathrm{CeO}_{2}(111)$ (Figure 10). After annealing to $500 \mathrm{~K}$ this feature disappears and is replaced by $\mathrm{CO}$ at $285.6 \mathrm{eV}$ and carbonate at $291 \mathrm{eV}$. The $\mathrm{CO}$ binding energy is lower than the binding energy for $\mathrm{CO} / \mathrm{Rh} / \mathrm{CeO}_{2}(111)$ however the shift is not as great as between $\mathrm{CO} / \mathrm{Rh}$ and $\mathrm{CO} / \mathrm{K} / \mathrm{Rh}$ (Figure 7) and therefore may not be definitive of a change in adsorption site. Note that the relative intensity of $\mathrm{CO}_{3}{ }^{2-}$ to $\mathrm{CO}$ is smaller on $\mathrm{K} / \mathrm{Rh} / \mathrm{CeO}_{2}(111)$ compared to $\mathrm{Rh} /$ $\mathrm{K} / \mathrm{CeO}_{2}(111)$ (Figure 9b) at $500 \mathrm{~K}$. This indicates that less of the adsorbed $\mathrm{CO}$ interacts with the $\mathrm{KO}_{\mathrm{X}}$ to form carbonate at this temperature. At $600 \mathrm{~K}$, after the lower temperature shoulders of 
$\mathrm{CO}$ and $\mathrm{K}$ have desorbed, most of the remaining $\mathrm{CO}$ has reacted with the $\mathrm{KO}_{\mathrm{X}}$ and formed $\mathrm{CO}_{3}{ }^{2-}$. Consistent with the TPD, all of the $\mathrm{C}$ is removed from the surface at $700 \mathrm{~K}$.

\section{Discussion}

The interaction of $\mathrm{CO}$ with $\mathrm{Rh}$ on $\mathrm{K}$-covered $\mathrm{CeO}_{2}(111)$ results from the adsorption of $\mathrm{CO}$ on the $\mathrm{Rh}$ which then spills-over and reacts with $\mathrm{KO}_{\mathrm{X}}$ on the ceria. As described in Section $3.1, \mathrm{~K}$ reacts with $\mathrm{CeO}_{2}(111)$ to produce $\mathrm{KO}_{\mathrm{X}}$. This is evident from the $\mathrm{K} 2 \mathrm{p}$ spectra (Figure 2) where the peak positions and line shapes indicate that the $\mathrm{K}$ is ionic and not metallic.[6,34] The $\mathrm{O}$ 1s spectra (Figure 5) indicate the formation of a new oxide, i.e. one that differs from $\mathrm{CeO}_{2}$, and the $\mathrm{Ce} 3 \mathrm{~d}$ spectra (Figure 4) indicate that the $\mathrm{Ce}$ is reduced, presumably because the $\mathrm{K}$ extracts $\mathrm{O}$ from the ceria to form $\mathrm{KO}_{\mathrm{X}}$.

(1) $\mathrm{CeO}_{2}+\mathrm{K} \rightarrow \mathrm{CeO}_{2-\mathrm{X}}+\mathrm{KO}_{\mathrm{X}}$

The precise stoichiometry of the $\mathrm{KO}_{\mathrm{X}}$ is not clear; however the $\mathrm{O} 1 \mathrm{~s}$ spectra indicate that only a small amount of $\mathrm{K}_{2} \mathrm{O}$ is formed and the $\mathrm{O}$ 1s peak at a higher binding energy than $\mathrm{CeO}_{2}$ is similar to that fromK $\mathrm{O}_{3}$ and $\mathrm{K}_{2} \mathrm{O}_{2}$.[35] It isn't known whether the $\mathrm{KO}_{\mathrm{X}}$ exists as a pure overlayer or whether a mixed oxide, $\mathrm{Ce}_{\mathrm{a}} \mathrm{K}_{\mathrm{b}} \mathrm{O}_{2}$, might be formed. It also isn't known whether the $\mathrm{KO}_{\mathrm{X}}$ forms continuous layers on the ceria or whether it forms islands. No ordered structure was observed in the LEED following $\mathrm{K}$ deposition or after annealing at various temperatures to lower the $\mathrm{K}$ coverage.Previous experiments have also indicated that the $\mathrm{O}$ mobility between the surface and the bulk in the ceria does not occur until above $500 \mathrm{~K}$.[27] Therefore the ceria reduction is probably confined to the surface layers since the $\mathrm{K} / \mathrm{CeO}_{2}$ film is only annealed to $350 \mathrm{~K}-400$ $\mathrm{K}$ before exposure to CO. In the TPD spectra, where the surface is heated to $900 \mathrm{~K}$, presumably $\mathrm{O}$ mobility from the bulk plays a role.

$\mathrm{CO}$ did not adsorb on $\mathrm{KO}_{\mathrm{X}} / \mathrm{CeO}_{2-\mathrm{x}}(111)$. $\mathrm{Rh}$ particles were needed to provide initial adsorption sites for the $\mathrm{CO}$. When $\mathrm{CO}$ is adsorbed on $\mathrm{Rh} / \mathrm{CeO}_{2}(111)$, in the absence of $\mathrm{K}$, the $\mathrm{CO}$ demonstrates very little interaction with the $\mathrm{CeO}_{2}(111)$ support and simply desorbs from the $\mathrm{Rh}$ by $600 \mathrm{~K}$ (Figure $8 \mathrm{a}$ ) in a manner similar to $\mathrm{CO}$ on $\mathrm{Rh}(111)$. When $\mathrm{K}$ is deposited before the Rhthe $\mathrm{C}$ 1s spectra indicate that at $350 \mathrm{~K} \mathrm{CO}$ on $\mathrm{Rh} / \mathrm{K} / \mathrm{CeO}_{2}(111)$ is largely the same as $\mathrm{CO}$ on $\mathrm{Rh} / \mathrm{CeO}_{2}(111)$ with $\mathrm{CO}$ adsorbed molecularly on the $\mathrm{Rh}$. More $\mathrm{CO}_{3}{ }^{2-}$ is formed on the oxide 
due to spillover from the $\mathrm{Rh}$ to the oxide when $\mathrm{K}$ is present than when it's absent (compare Figure $9 \mathrm{a}$ and $9 \mathrm{~b}$ ). However, as the sample is heated additional CO spills-over from the Rh to the $\mathrm{KO}_{\mathrm{X}}$ to form carbonate, and $\mathrm{CO}$ and $\mathrm{CO}_{2}$ desorbbetween $350 \mathrm{~K}$ and $550 \mathrm{~K}$. Presumably some of the desorbed $\mathrm{CO}$ results from molecular desorption directly from the Rh particle. This is suggested by the overlap of this desorption with the $\mathrm{CO}$ that desorbed from $\mathrm{Rh} / \mathrm{CeO}_{2}(111)$ in the absence of $\mathrm{K}$ (compare Figures $8 \mathrm{a}$ and $8 \mathrm{~b}$ ). The relative amount of ${ }^{13} \mathrm{C}^{18} \mathrm{O}$ to ${ }^{13} \mathrm{C}^{16} \mathrm{O}$ in this temperature range also indicates little loss of ${ }^{18} \mathrm{O}$ in the $\mathrm{CO}$ and therefore little interaction with the oxide. However, a large amount of $\mathrm{CO}_{2}$ is also formed in this temperature range which could only have resulted from a reaction between the $\mathrm{CO}$ and the oxide. It isn't known whether this $\mathrm{CO}_{2}$ formed from a direct reaction between the $\mathrm{CO}$ and the oxide or whether it went through a $\mathrm{CO}_{3}{ }^{2-}$ intermediate that then decomposed to $\mathrm{CO}_{2}$.

The large $\mathrm{CO}$ desorption peak that occurs near $620 \mathrm{~K}$ results from the decomposition of carbonate since, based on the $\mathrm{C} 1 \mathrm{~s}$ spectra (Figure 9), there is only a small amount of CO present at $500 \mathrm{~K}$ and at $600 \mathrm{~K}$ carbonate is the only $\mathrm{C}$-containing species on the surface. Interestingly this $\mathrm{CO}$ desorbs before the $\mathrm{K}$ (Figure 8). This is very different from $\mathrm{CO}$ co-adsorbed with $\mathrm{K}$ on $\mathrm{Rh} / \mathrm{Ru}(0001$ ) in (Figure 6b) where $\mathrm{CO}$ and $\mathrm{K}$ stabilize each other and desorbed together at a temperature that is higher than either adsorbed on Rh separately. In the case of CO adsorbed on $\mathrm{Rh} / \mathrm{KO}_{\mathrm{X}} / \mathrm{CeO}_{2-\mathrm{x}}(111)$ the $\mathrm{K}$ desorbs at the same temperature as $\mathrm{CO}_{2}$. The potassium carbonate therefore appears to decompose in two steps; the first liberates $\mathrm{CO}$ leaving $\mathrm{KO}_{\mathrm{X}}$ on the surface, the second produces $\mathrm{CO}_{2}(\mathrm{~g})$ and $\mathrm{K}(\mathrm{g})$.

Above the $\mathrm{CO}_{2}$ desorption peak near $700 \mathrm{~K}$ there is no $\mathrm{C}$ remaining on the surfacebut $\mathrm{KO}_{\mathrm{X}}$ continues to decompose producing $\mathrm{K}(\mathrm{g})$. In this respect $\mathrm{CO} / \mathrm{Rh} / \mathrm{K} / \mathrm{CeO}_{2}(111)$ is similar to $\mathrm{CO} / \mathrm{K} / \mathrm{Rh}(111)$. The $\mathrm{CO}$ and the $\mathrm{K}$ or $\mathrm{KO}_{\mathrm{X}}$ form complexes which stabilizes each of them, but when the $\mathrm{CO}$ or $\mathrm{CO}_{2}$ is gone some $\mathrm{K}$ remains behind which is then desorbed at higher temperatures.

The formation of $\mathrm{CO}_{2}$ requires a reaction between $\mathrm{CO}$ and the oxidized substrate. Presumably this should reduce $\mathrm{Ce}^{4+}$ to $\mathrm{Ce}^{3+}$. $\mathrm{No} \mathrm{Ce}^{3+}$ was detected in either the $\mathrm{Ce} 3 \mathrm{~d}$ or $\mathrm{Ce} 4 \mathrm{~d}$ spectra recorded after $\mathrm{CO} / \mathrm{Rh} / \mathrm{K} / \mathrm{CeO}_{2}(111)$ was annealed to $900 \mathrm{~K}$ (data not shown). This observation can be rationalized as resulting from the diffusion of $\mathrm{O}$ from deeper layers in the $\mathrm{CeO}_{2-\mathrm{X}}(111)$ film which dilutes the $\mathrm{Ce}^{3+}$ in the near-surface layers which are sampled by XPS. Similar results have been observed for methanol on oxidized $\mathrm{CeO}_{2}(111)[29]$ and water on 
reduced $\mathrm{CeO}_{2-\mathrm{x}}(111)[27]$ where single adsorption / desorption cycles do not alter the apparent oxidation state of the Ce despite reactions that remove or deposit $\mathrm{O}$.

The $\mathrm{CO}$ reaction and desorption behavior changes dramatically if the $\mathrm{K}$ is deposited after the $\mathrm{Rh}$ rather than before. When $\mathrm{K}$ is deposited after the $\mathrm{Rh}$ we assume that the $\mathrm{K}$ adheres to both the $\mathrm{Rh}$ and the $\mathrm{CeO}_{2}$ although we don't know if some of the $\mathrm{K}$ might have spilled over from the $\mathrm{Rh}$ to the ceria. There are two prominent differences in the adsorption and reaction of $\mathrm{CO}$ adsorbed on $\mathrm{K} / \mathrm{Rh} / \mathrm{CeO}_{2}(111)$ (Figure 10) and $\mathrm{CO}$ adsorbed on $\mathrm{Rh} / \mathrm{K} / \mathrm{CeO}_{2}(111)$ (Figure $8 b$ ). The $\mathrm{CO}_{2}$ desorption between $500 \mathrm{~K}$ and $700 \mathrm{~K}$ is considerably reduced and is replaced by $\mathrm{CO}$ desorption. In this way the $\mathrm{CO}$ desorption is more similar to $\mathrm{CO}$ on $\mathrm{K} / \mathrm{Rh}$ (Figure 6b). The peak in the $\mathrm{CO}$ desorption is closer to the peak in the $\mathrm{K}$ desorption although it still precedes it by about ten degrees. Note, however, that the K desorption (blue line) is broad and actually precedes the $\mathrm{CO}$ desorption at the lower end.

The second major difference between $\mathrm{CO}$ on $\mathrm{K} / \mathrm{Rh} / \mathrm{CeO}_{2}(111)$ and $\mathrm{CO}$ on $\mathrm{Rh} / \mathrm{K} /$ $\mathrm{CeO}_{2}(111)$ is the low temperature $\mathrm{CO}$ desorption that occurs between $200 \mathrm{~K}$ and $340 \mathrm{~K}$. This desorption is associated with the $\mathrm{C} 1 \mathrm{~s}$ peak at $288 \mathrm{eV}$ (Figure 11) and has been assigned to $\mathrm{CO}_{2}{ }^{-}$. $\mathrm{CO}_{2}^{-}$has been reported following $\mathrm{CO}_{2}$ adsorption on $\mathrm{K} / \mathrm{Cu}(110)[41], \mathrm{K} / \mathrm{Pd}(110)[40], \mathrm{K} /$ $\mathrm{Pt}(111)[42]$ and $\mathrm{K} / \mathrm{Rh}$ (111).[43] The most commonly proposed mechanisms for $\mathrm{CO}_{2}{ }^{-}$formation involve the transfer of an electron from $\mathrm{K}$ to $\mathrm{CO}_{2}$.

(2) $\mathrm{K}+\mathrm{CO}_{2} \rightarrow \mathrm{K}^{+} \mathrm{CO}_{2}^{-}$

As the surface is heated the $\mathrm{CO}_{2}{ }^{-}$disproportionates into $\mathrm{CO}$ and $\mathrm{CO}_{3}{ }^{2-}$.

(3) $2 \mathrm{CO}_{2}{ }^{-} \rightarrow \mathrm{CO}+\mathrm{CO}_{3}{ }^{2-}$

The disproportionation is evident in the $\mathrm{C} 1 \mathrm{~s}$ spectra (Figure 11) where $\mathrm{CO}_{2}{ }^{-}$at $200 \mathrm{~K}$ is replaced by $\mathrm{CO}$ and $\mathrm{CO}_{3}{ }^{2-}$ at $500 \mathrm{~K}$. Following this disproportionation some of the $\mathrm{CO}$ immediately desorbsand some remains on the surface to desorb later. The carbonate remains on the surface and decomposes at a higher temperature.Only in the case of $\mathrm{CO}_{2}$ adsorbed on $\mathrm{K} /$ $\mathrm{Cu}(110)$ was a new, low temperature $\mathrm{CO}$ desorption state near $200 \mathrm{~K}$ observed. 
In the case of $\mathrm{CO}$ adsorbed on $\mathrm{K} / \mathrm{Rh} / \mathrm{CeO}_{2}(111)$ it appears that the $\mathrm{CO}$ reacts with $\mathrm{O}$ from the substrate to produce $\mathrm{CO}_{2}{ }^{-}$upon exposure at $200 \mathrm{~K}$. Two possible mechanisms are that the $\mathrm{CO}$ reacts with the substrate to form $\mathrm{CO}_{2}$ which then binds to $\mathrm{K}$ on the $\mathrm{Rh}$ to stabilize $\mathrm{K}^{+} \mathrm{CO}_{2}^{-}$, or that $\mathrm{O}$ from the substrate initially reacts with $\mathrm{K}$ on the $\mathrm{Rh}$ to form $\mathrm{KO}_{\mathrm{X}}$ which then reacts with $\mathrm{CO}$ to form $\mathrm{K}^{+} \mathrm{CO}_{2}^{-}$. The current data does not support one mechanism over the other. However, almost all of the $\mathrm{CO}$ forms $\mathrm{CO}_{2}{ }^{-}$upon adsorption on $\mathrm{K} / \mathrm{Rh} / \mathrm{CeO}_{2}(111)$ at $200 \mathrm{~K}$. Contrast this with $\mathrm{CO}$ adsorption on $\mathrm{Rh} / \mathrm{CeO}_{2}$ (Figure 9a) or $\mathrm{Rh} / \mathrm{K} / \mathrm{CeO}_{2}(111)$ (Figure 9b) where there is no evidence of $\mathrm{CO}_{2}$ or $\mathrm{CO}_{2}^{-}$formation. This suggests that $\mathrm{CO}$ is reacting with $\mathrm{K}$ and $\mathrm{O}$ on the $\mathrm{Rh}$ particle rather than with $\mathrm{O}$ still in the substrate at the periphery of the particle.

Note that the weighted ${ }^{13} \mathrm{C}^{18} \mathrm{O}$ at $300 \mathrm{~K}$ is roughly half the intensity relative to the ${ }^{13} \mathrm{C}^{16} \mathrm{O}$ compared to isotopically labeled $\mathrm{CO}$ on $\mathrm{Rh}, \mathrm{K} / \mathrm{Rh}$ (Figure 6) or $\mathrm{Rh} / \mathrm{CeO}_{2}(111)$ (Figure 8a). This is consistent with the decomposition of $\left({ }^{18} \mathrm{O}^{13} \mathrm{C}^{16} \mathrm{O}\right)$ - where half of the ${ }^{18} \mathrm{O}$ would be lost after random decomposition. In the $\mathrm{CO}$ that desorbs at higher temperature the relative amount of ${ }^{13} \mathrm{C}^{18} \mathrm{O}$ is even smaller reflecting the dilution of ${ }^{18} \mathrm{O}$ in $\left({ }^{13} \mathrm{C}^{18} \mathrm{O}^{16} \mathrm{O}_{2}\right)^{2-}$.

A remaining question is why $\mathrm{CO}$ desorption increases while $\mathrm{CO}_{2}$ desorption decreases at higher temperature on $\mathrm{K} / \mathrm{Rh} / \mathrm{CeO}_{2}(111)$ compared to $\mathrm{Rh} / \mathrm{K} / \mathrm{CeO}_{2}(111)$. This is partly explained by the persistence of molecular $\mathrm{CO}$ at $500 \mathrm{~K}$ and $600 \mathrm{~K}$ (Figure 11) which desorbs directly as CO. In addition, some or all of the carbonate that is formed following the disproportionation of $\mathrm{CO}_{2}^{-}$may persist on the $\mathrm{Rh}$ rather than spill-over onto the $\mathrm{KO}_{\mathrm{X}} /$ $\mathrm{CeO}_{2}(111)$. The decomposition of this carbonate may favor $\mathrm{CO}$ formation rather than $\mathrm{CO}_{2}$ formation. Also note that the $\mathrm{K}$ desorption isn't completely stabilized by the $\mathrm{CO}$ adsorbate (Figure 10). It starts to desorb near $500 \mathrm{~K}$ before the $\mathrm{CO}$ and $\mathrm{CO}_{2}$. This may result from $\mathrm{KO}_{\mathrm{X}}$ on the ceria that hasn't reacted with $\mathrm{CO}$. Because of the $\mathrm{K}$ on the Rh the $\mathrm{CO}$ that adsorbs on the Rh stays on the $\mathrm{Rh}$ rather spilling over onto the $\mathrm{KO}_{\mathrm{X}}$.

Finally, there is no indication of atomic $\mathrm{C}$ produced by $\mathrm{CO}$ dissociation in any of the $\mathrm{C} 1 \mathrm{~s}$ data. Therefore the mere presence of $\mathrm{Ce}^{3+}$ was not sufficient to induce dissociation in the $\mathrm{CO}$ adsorbed on the $\mathrm{Rh}$ particle. However there are too many other interactions occurring in the present systems that preclude drawing any conclusions as to the role of $\mathrm{Ce}^{3+}$ in the dissociation of $\mathrm{CO}$ on $\mathrm{Rh} / \mathrm{CeO}_{2-\mathrm{x}}(111)$. The $\mathrm{K}$ coverage studied in this work was relatively hightherefore the $\mathrm{Rh}$ may not have been in contact with the ceria, nor might there have been any ceria exposed at the $\mathrm{Rh} /$ oxide interface. Further the interactions between $\mathrm{CO} / \mathrm{KO}_{\mathrm{x}}$ or $\mathrm{CO} / \mathrm{K}$ may have been 
stronger than any possible interactions between $\mathrm{CO} / \mathrm{Rh} / \mathrm{Ce}^{3+}$. However, there is one significant similarity between $\mathrm{CO} / \mathrm{Rh} / \mathrm{K} / \mathrm{CeO}_{2}(111)$ and $\mathrm{CO} / \mathrm{Rh} / \mathrm{CeO}_{2-\mathrm{x}}(111)$. In both cases it was possible for the oxide to affect all of the $\mathrm{CO}$ adsorbed on the Rh particle. In the case of $\mathrm{CO} / \mathrm{Rh} /$

$\mathrm{K} / \mathrm{CeO}_{2}(111)$ all of the $\mathrm{CO}$ forms $\mathrm{CO}_{3}{ }^{2-}$ upon annealing. On $\mathrm{Rh} / \mathrm{CeO}_{2-\mathrm{X}}(111)$ it was possible to dissociate all of the $\mathrm{CO}$, provided the ceria was highly reduced.[24] The formation of $\mathrm{CO}_{3}{ }^{2-}$ can only occur at the periphery of the particles since it requires reaction with $\mathrm{O}$ from the substrate. Therefore even the CO that is adsorbed away from the edge can migrate to the edge to react, and the $\mathrm{CO}$ that was initially at the edge doesn't block this reaction after it forms $\mathrm{CO}_{3}{ }^{2-}$. This suggests that $\mathrm{CO}$ dissociation on $\mathrm{Rh} / \mathrm{CeO}_{2-\mathrm{x}}(111)$ may similarly be an "edge effect" where $\mathrm{CO}$ at the periphery reacts with $\mathrm{Ce}^{3+}$, or an $\mathrm{O}$ vacancy, in the substrate.

\section{Conclusions}

$\mathrm{K}$ deposited on $\mathrm{CeO}_{2}(111)$ forms a $\mathrm{KO}_{\mathrm{X}}$ over-layer by extracting $\mathrm{O}$ from the ceria and partially reducing some of the $\mathrm{Ce}^{4+}$ to $\mathrm{Ce}^{3+}$.This surface does not form an ordered structure as detected by LEED. Approximately $13 \mathrm{~nm}^{-2}$ of $\mathrm{KO}_{\mathrm{X}}$ forms before the $\mathrm{K}$ no longer reacts with the ceria and multilayer metallic $\mathrm{K}$ is deposited. $\mathrm{CO}$ does not adsorb on the $\mathrm{KO}_{\mathrm{X}} / \mathrm{CeO}_{2-\mathrm{X}}(111)$ surface without $\mathrm{Rh}$. $\mathrm{CO}$ adsorbed on $\mathrm{Rh} / \mathrm{K} / \mathrm{CeO}_{2}(111)$ adsorbs molecularly on the $\mathrm{Rh}$ at 200 $\mathrm{K}$. As the surface is heated the $\mathrm{CO}$ spills-over and reacts with the $\mathrm{KO}_{\mathrm{X}}$ to form carbonate. The carbonate decomposes at elevated temperature to produce $\mathrm{CO}$ and $\mathrm{CO}_{2}$. The carbonate stabilizes the $\mathrm{KO}_{\mathrm{X}}$ so that it desorbs at a higher temperature than it would in the absence of $\mathrm{CO}$. When the $\mathrm{Rh}$ and $\mathrm{K}$ deposition are reversed so that $\mathrm{K}$ is deposited on both $\mathrm{Rh}$ and $\mathrm{CeO}_{2}(111)$, $\mathrm{CO}$ adsorbs as $\mathrm{CO}_{2}{ }^{-}$at $200 \mathrm{~K}$. The $\mathrm{CO}_{2}^{-}$decomposes below $350 \mathrm{~K}$ to produce gas phase $\mathrm{CO}$ and adsorbed $\mathrm{CO}_{3}{ }^{2-}$ and $\mathrm{CO}$. The $\mathrm{CO}$ is stabilized by the $\mathrm{K}$ on the $\mathrm{Rh}$ and desorbs above $540 \mathrm{~K}$. The carbonate decomposes into gas phase $\mathrm{CO}$ and $\mathrm{CO}_{2}$. The $\mathrm{K}$ deposited directly onto the $\mathrm{Rh}$ prevents some of the $\mathrm{CO}$ from spilling over onto the $\mathrm{KO}_{\mathrm{X}}$. This leaves some of the $\mathrm{K}$ on the ceria is unaffected by the $\mathrm{CO}$ and enables it to desorb before the $\mathrm{C}$-containing products. 


\section{Acknowledgements}

This work was supported by the U.S. Department of Energy, Office of Science, Basic Energy Sciences, Chemical Sciences, Geosciences, and Biosciences Division. Research carried out in part at the National Synchrotron Light Source, Brookhaven National Laboratory, which issupported by the US Department of Energy, Office of Science, Office of Basic Energy Sciences, under Contract DEAC02-98CH10886. 


\section{References}

[1] W.D. Mross,Alkali Doping in Heterogeneous Catalysis, Catalysis Reviews-Science and Engineering 25 (1983) 591-637.

[2] H.P. Bonzel,Alkali-Metal-Affected Adsorption of Molecules on Metal-Surfaces, Surface Science Reports 8 (1988) 43-125.

[3] J. Kiss, G. Klivenyi, K. Revesz, F. Solymosi,Photoelectron Spectroscopic Studies on the Dissociation of CO on Potassium-Dosed Rh(111) Surface, Surface Science 223 (1989) 551-568.

[4] J.E. Crowell, G.A. Somorjai,The Effect of Potassium on the Chemisorption of CarbonMonoxide on the Rh(111) Crystal-Face, Applied Surface Science 19 (1984) 73-91.

[5] J.J. Weimer, E. Umbach, D. Menzel,The Properties of K and Coadsorbed CO + K on $\mathrm{Ru}(001$.1. Adsorption, Desorption, and Structure, Surface Science 155 (1985) 132-152.

[6] J.J. Weimer, E. Umbach, D. Menzel, The Properties of K and Coadsorbed CO + K on Ru (001) .2. Electronic-Structure, Surface Science 159 (1985) 83-107.

[7] J.E. Crowell, W.T. Tysoe, G.A. Somorjai,Potassium Coadsorption Induced Dissociation of CO on the Rh(111) Crystal-Surface - an Isotope Mixing Study, Journal of Physical Chemistry 89 (1985) 1598-1601.

[8] M.P. Kiskinova,CO Adsorption on Alkali-Metal Covered Ni(100), Surface Science 111 (1981) 584-594.

[9] L.J. Whitman, W. Ho, The Effects of Surface Geometry and Island Formation on AlkaliPromoted Surfaces - the Coadsorption of CO and K on Ni(110), Journal of Chemical Physics 83 (1985) 4808-4816.

[10] A.T. Bell,Catalytic Synthesis of Hydrocarbons over Group-Viii Metals - a Discussion of the Reaction-Mechanism, Catalysis Reviews-Science and Engineering 23 (1981) 203-232.

[11] M.A. Barteau,Organic reactions at well-defined oxide surfaces, Chemical Reviews 96 (1996) 1413-1430.

[12] R. Lindsay, E. Michelangeli, B.G. Daniels, M. Polcik, A. Verdini, L. Floreano, A. Morgante, J. Muscat, N.M. Harrison, G. Thornton,Surface to bulk charge transfer at an alkali metal/metal oxide interface, Surface Science 547 (2003) L859-L864.

[13] B.E. Hayden, G.P. Nicholson,An Ellipsometric Study of Potassium Adsorption of $\mathrm{TiO}_{2}$ (110), Surface Science 274 (1992) 277-286.

[14] R. Heise, R. Courths,A Photoemission Investigation of the Adsorption of Potassium on Perfect and Defective $\mathrm{TiO}_{2}$ (110) Surfaces, Surface Science 331 (1995) 1460-1466.

[15] M. Wilde, I. Beauport, F. Stuhl, K. Al-Shamery, H.J. Freund,Adsorption of potassium on $\mathrm{Cr}_{2} \mathrm{O}_{3}(0001)$ at ionic and metallic coverages and uv-laser-induced desorption, Physical Review B 59 (1999) 13401-13412.

[16] W. Zhao, G. Kerner, M. Asscher, X.M. Wilde, K. Al-Shamery, H.J. Freund, V. Staemmler, M. Wieszbowska,Interaction and diffusion of potassium on $\mathrm{Cr}_{2} \mathrm{O}_{3}(0001) / \mathrm{Cr}(110)$, Physical Review B 62 (2000) 7527-7534.

[17] K. Ozawa, K. Edamoto,Photoelectron spectroscopy study of K adsorption on $\mathrm{ZnO}(10$ (1)over-bar 0), Surface Science 524 (2003) 78-88.

[18] K. Ozawa, K. Edamoto,Photoelectron spectroscopy study of the K-covered ZnO(1 0 (1)over-bar 0) surface; annealing-induced changes in the electronic structure and the chemical composition, Surface Science 547 (2003) 257-267.

[19] H.H. Huang, X. Jiang, Z. Zou, W.S. Chin, G.Q. Xu, W.L. Dai, K.N. Fan, J.F. Deng,Potassium adsorption and reaction with water on $\mathrm{MgO}(100)$, Surface Science 412-13 (1998) 555-561. 
[20] H.H. Huang, X. Jiang, Z. Zou, G.Q. Xu,Interaction of atomic hydrogen with potassium on $\mathrm{MgO}(100)$, Surface Science 376 (1997) 245-253.

[21] M. Schulze, R. Reissner,Reaction of potassium with thin epitaxial $\mathrm{NiO}(100)$ films, Surface Science 507 (2002) 851-858.

[22] J. Stubenrauch, J.M. Vohs,Interaction of $\mathrm{CO}$ with Rh supported on stoichiometric and reduced $\mathrm{CeO}_{2}(111)$ and $\mathrm{CeO}_{2}(100)$ surfaces, Journal of Catalysis 159 (1996) 50-57.

[23] J. Stubenrauch, J.M. Vohs,Support effects in the dissociation of $\mathrm{CO}$ on $\mathrm{Rh} / \mathrm{CeO}_{2}(111)$, Catalysis Letters 47 (1997) 21-25.

[24] D.R. Mullins, S.H. Overbury,CO dissociation on Rh deposited on reduced cerium oxide thin films, Journal of Catalysis 188 (1999) 340-345.

[25] D.R. Mullins, P.V. Radulovic, S.H. Overbury,Ordered cerium oxide thin films grown on $\mathrm{Ru}(0001)$ and $\mathrm{Ni}(111)$, Surface Science 429 (1999) 186-198.

[26] P.L. Hagans, B.M. Dekoven, J.L. Womack,A Laser Drilled Aperture for Use in an Ultrahigh-Vacuum Gas Doser, Journal of Vacuum Science \& Technology a-Vacuum Surfaces and Films 7 (1989) 3375-3377.

[27] L. Kundakovic, D.R. Mullins, S.H. Overbury,Adsorption and reaction of $\mathrm{H}_{2} \mathrm{O}$ and $\mathrm{CO}$ on oxidized and reduced $\mathrm{Rh} / \mathrm{CeOx}(111)$ surfaces, Surface Science 457 (2000) 51-62.

[28] D.R. Mullins, K.Z. Zhang,Metal-support interactions between Pt and thin film cerium oxide, Surface Science 513 (2002) 163-173.

[29] D.R. Mullins, M.D. Robbins, J. Zhou,Adsorption and reaction of methanol on thin-film cerium oxide, Surface Science 600 (2006) 1547-1558.

[30] D.R. Mullins, S.H. Overbury, D.R. Huntley,Electron spectroscopy of single crystal and polycrystalline cerium oxide surfaces, Surface Science 409 (1998) 307-319.

[31] J. Hrbek, M.L. Shek, T.K. Sham, G.Q. Xu,Layer Resolved Spectroscopy of Potassium Adsorbed on a $\mathrm{Ru}(001)$ Surface - Photoemission and Thermal-Desorption Study, Journal of Chemical Physics 91 (1989) 5786-5792.

[32] G.H. Rocker, C. Huang, C.L. Cobb, J.D. Redding, H. Metiu, R.M. Martin, The Interaction of Oxygen and Potassium on the Ru(001) Surface, Surface Science 250 (1991) 33-50.

[33] D.A. Shirley,High-Resolution X-Ray Photoemission Spectrum of Valence Bands of Gold, Physical Review B 5 (1972) 4709-\&.

[34] G. Pirug, A. Winkler, H.P. Bonzel,Multilayer Growth of Potassium on a Pt(111) Surface, Surface Science 163 (1985) 153-171.

[35] B. Lamontagne, F. Semond, D. Roy,K Overlayer Oxidation Studied by XPS - the Effects of the Adsorption and Oxidation Conditions, Surface Science 327 (1995) 371-378.

[36] M.P. Seah, W.A. Dench,Quantitative electron spectroscopy of surfaces: A standard data base for electron inelastic mean free paths in solids, Surface and Interface Analysis 1 (1979) 211 .

[37] C.J. Powell, A. Jablonski, I.S. Tilinin, S. Tanuma, D.R. Penn,Surface sensitivity of Auger-electron spectroscopy and X-ray photoelectron spectroscopy, Journal of Electron Spectroscopy and Related Phenomena 98 (1999) 1-15.

[38] F. Strisland, A. Beutler, A.J. Jaworowski, R. Nyholm, B. Setlik, D. Heskett, J.N. Andersen,Adsorption sites in coadsorption systems determined by photoemission spectroscopy: $\mathrm{K}$ and CO coadsorbed on Rh(111), Surface Science 410 (1998) 330-343.

[39] P.M. Albrecht, D.E. Jiang, D.R. Mullins, CO2 Adsorption As a Flat-Lying, Tridentate Carbonate on $\mathrm{CeO}_{2}$ (100), Journal of Physical Chemistry C 118 (2014) 9042-9050. 
[40] S.J. Pratt, D.A. King,Coverage dependent promoter action: K coadsorption and reactions with $\mathrm{CO}$ and $\mathrm{CO}_{2}$ on $\mathrm{Pd}\{110\}$, Surface Science 540 (2003) 185-206.

[41] E.V. Thomsen, B. Jorgensen, J. Onsgaard,Adsorption and Reactivity of $\mathrm{CO}_{2}$ on the $\mathrm{K} / \mathrm{Cu}(110)$ Interface and the Effect of Photon Irradiation, Surface Science 304 (1994) 85-97.

[42] Z.M. Liu, Y. Zhou, F. Solymosi, J.M. White,Spectroscopic Study of K-Induced Activation of $\mathrm{CO}_{2}$ on Pt(111), Surface Science 245 (1991) 289-304.

[43] J. Kiss, K. Revesz, F. Solymosi,Photoelectron Spectroscopic Studies of the Adsorption of $\mathrm{CO}_{2}$ on Potassium-Promoted Rh(111) Surface, Surface Science 207 (1988) 36-54. 


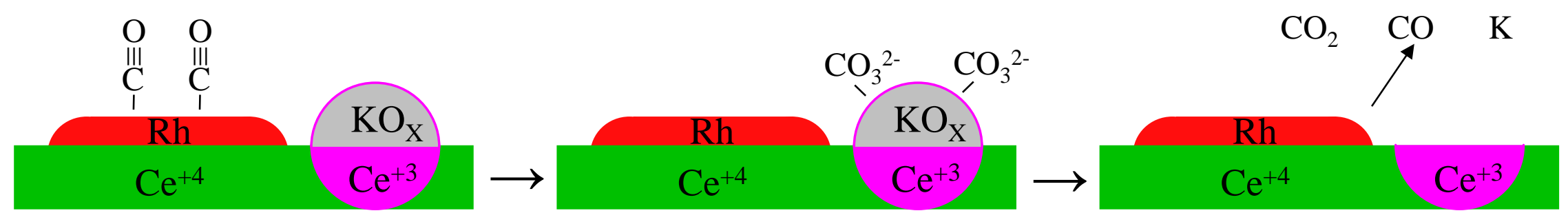

$\mathrm{CO} / \mathrm{Rh} / \mathrm{K} / \mathrm{CeO}_{2}(111)$

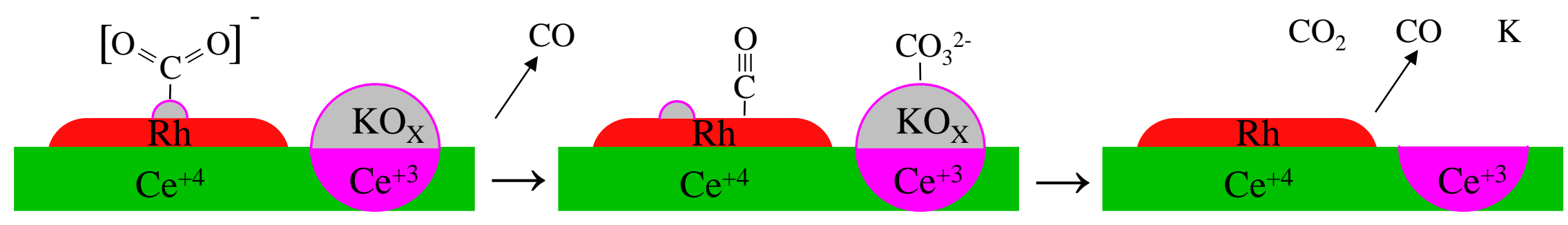

$\mathrm{CO} / \mathrm{K} / \mathrm{Rh} / \mathrm{CeO}_{2}(111)$ 